\title{
Auditor Independence and the Cost of Capital Before and After Sarbanes-Oxley: The Case of Newly Issued Public Debt
}

\author{
Eli Amir \\ London Business School \\ Regent's Park \\ London NW1 4SA \\ eamir@,london.edu \\ Yanling Guan \\ School of Business \\ The University of Hong Kong \\ ylguan@,business.hku.hk \\ and \\ Gilad Livne \\ Cass Business School \\ City University of London \\ London EC1Y 8TZ \\ g.livne@city.ac.uk
}

15 November 2009

We would like to thank Salvador Carmona (Editor), two anonymous reviewers, David Citron, Eti Einhorn, Miles Gietzmann, Clive Lennox, L. Shivakumar and seminar participants at Cardiff University and IDC Herzliya for useful comments and suggestions. 


\title{
Auditor Independence and the Cost of Capital Before and After Sarbanes- Oxley: The Case of Newly Issued Public Debt
}

\begin{abstract}
An important aim of the Sarbanes-Oxley Act $(S O X)$ was to reduce cost of capital by enhancing auditor independence. However, prior literature has argued that $S O X$ has been ineffective in meeting this objective. We contribute to this debate by first providing evidence suggesting that auditor independence has increased following SOX. Though we posit an inverse relationship between auditor independence and cost of capital, it is an open question whether this relationship has become stronger or weaker following $S O X$. An examination of this relationship reveals that auditor independence is more strongly related to bond rating and bond yield premium in the postSOX period relative to the period before $S O X$. This evidence supports the argument that $S O X$ has created benefits that resulted in lower cost of borrowing.
\end{abstract}

Keywords: Sarbanes-Oxley Act $(S O X)$, Auditor Independence, Cost of Capital, Bond Rating, Yield Spread

JEL classifications: M41, M42, G12 


\section{Auditor Independence and the Cost of Capital Before and After Sarbanes- Oxley: The Case of Newly Issued Public Debt}

\section{Introduction}

Better quality of financial information attracts higher valuations because investors can measure future cash flows with greater degree of certainty. This implies that the cost of capital is inversely related to the degree of reliability in reported financial figures (Dye, 2001; Verrecchia, 2001; Easley and O’Hara, 2004; Gietzmann and Ireland, 2005; Nikolaev and Van Lent, 2005). Because auditors can influence managers' reporting practices, the literature also suggests that auditor independence and reliability of financial reporting are positively related (Kinney et al., 2004). Independent auditors can also provide effective monitoring to deter fraud and wasteful actions at the expense of lenders and shareholders (DeAngelo, 1981). As a result, firms audited by more independent auditors are expected to benefit from lower cost capital. The scant research on the association between auditor independence and the cost of capital confirms this hypothesis (Khurana and Raman, 2006; Brandon et al., 2004; Dhaliwal et al., 2009)

The accounting scandals in the early 2000 s prompted U.S. legislators to pass the SarbanesOxley Act $(S O X)$ of 2002. Among other objectives, the aim of the act was to enhance auditor independence as a means to reducing cost of capital. The SEC (2003) has maintained that potential benefits include increased investor confidence in the independence of accountants, in the audit process, and in the reliability of reported financial information, which would result in a lower cost of capital. ${ }^{1}$ But little is empirically known if SOX has been successful in meeting this objective. To shed light on this question, we examine if the inverse relationship between auditor independence and cost of capital has become stronger or weaker following SOX. Evidence that auditor independence is higher coupled with stronger inverse relationship between cost of 
capital and auditor independence would support the argument that SOX has been successful in meeting its stated objective, namely, a unit of auditor independence is priced in capital markets more after $S O X$ than before.

We develop a model in which an auditor optimally decides on the level of independence. This decision is influenced by the level of fees she can charge for reducing her independence against litigation and reputation costs, that arise when quality of reported numbers is poorer or monitoring and fraud detection are less effective. Investors in turn price the client's securities taking into account the quality of information and the strength of monitoring by auditors. Consistent with prior literature, better disclosure and monitoring lead to higher valuation because they involve higher cash flows and less information asymmetry. In this model, cost of capital is therefore inversely related to auditor independence. The various requirements of $S O X$ (see below) affect the level of independence chosen by the auditor by changing the cost-benefit analysis she faces. This, in turn, may enhance or weaken the positive relationships between independence on one hand and monitoring and quality of disclosure on the other hand, depending on the assumed functional relationships. As a result, the magnitude of the negative relationship between auditor independence and cost of capital may be stronger or weaker following $S O X$. Hence, this is ultimately an empirical issue. However, we show that under certain conditions an increase in auditor independence following $S O X$ is expected to increase the magnitude of this relationship.

There are a number of reasons why $S O X$ is expected to enhance auditor independence. First, SOX may have forced firms and external auditors to implement mechanisms that are capable of reducing misreporting. Second, by barring auditors from providing certain non-audit services (NAS), SOX may have forced auditors to direct more effort to the audit task and to 
better monitoring of potentially fraudulent activities. Prior to this change, audit services may have been provided at a loss, reducing their effectiveness. Furthermore, the establishment of the Public Company Accounting Oversight Board $(P C A O B)$, a quasi-governmental agency, has fundamentally changed the regulation of the audit profession, which previously was selfregulated (DeFond and Francis, 2005). As a result, auditors face tougher scrutiny and tighter enforcement following $S O X$. Third, SOX makes it unlawful to exert improper influence on external auditors. Collectively, these requirements imply that the costs associated with weak independence should increase following $S O X$, suggesting that, ceteris paribus, the level of auditor independence should increase after SOX. However, a number of commentators have argued that it is unclear whether $S O X$ has been effective in changing auditors' incentives and the way they operate (e.g., Ribstein, 2002; DeFond and Francis, 2005).

We use the primary bond market in our empirical assessment of the effect of $S O X$ on the cost of capital. We use bond ratings and yield premium as measures of cost of debt capital. We use the bond market because the pricing of debt is better defined and easily measured than that of equity (Mansi et al., 2004). This allows sharper inferences because there is no need to rely on inherently noisy models for estimating the cost of equity capital. Also, accounting research tends to focus on valuation effects on equity, however, as debt markets are larger than equity markets, it is important to consider the effects of auditor independence on the pricing of debt.

Our sample contains public firms that actively and often repeatedly issue debt and for which any changes in ratings and the cost of debt are expected to have material impact on cash flows. Since secondary markets are less liquid, using the primary bond market avoids measurement issues due to stale prices or ratings. Furthermore, within this sample we also 
identify a subset of companies that issued bonds both before and after SOX. As such, reported findings are less sensitive to variation in firm-specific effects.

An economic dependence between external auditors and their clients may arise when an auditor relies on fees for non-audit services (NAS) or when an individual client generates an unusually high proportion of the auditor's total fee income. By offering a more profitable line of business, auditors may sacrifice independence in the audit task and risk litigation in order to maintain the more lucrative engagements (Levitt, 2000; Pany and Reckers, 1983; DeFond et al., 2002). Thus, consistent with prior studies, our first measure of auditor independence is based on the ratio of audit fees to total (i.e., audit fees plus non-audit) fees. The second measure is the log of total fees paid to the auditor, which unlike the first measure, is sensitive to scaling effects and may provide a better reflection of the importance of a client to the auditor's business (Ashbaugh et al., 2003; DeFond and Francis, 2005). We regress these two measures on firm-specific, auditor-specific and task-complexity factors, consistent with models used by Kinney and Libby (2002), Frankel et al., (2002), and Ruddock et al., (2006). Then, we estimate auditor independence as the unexpected ratio of audit fees to total fees and the unexpected component of total fees, respectively.

We first document evidence consistent with a positive effect of $S O X$ on auditor independence. We then find stronger positive association between auditor independence and bond ratings for bonds issued in the post-SOX period than for bonds issued before SOX was enacted. We also find stronger negative association between auditor independence and yield spreads in the post-SOX period. These findings are robust to additional sensitivity analyses, such as controlling for multiple issues by the same firms and examining a sample of firms that issue debt both in the pre- and post-SOX periods. Collectively, these findings support the view that 
SOX enhanced auditor independence and, as a result, lowered cost of debt capital. The finding that auditor independence is more strongly related to cost of debt capital after $S O X$ than before is consistent with auditor independence becoming more credible for monitoring and reporting purposes after $S O X$.

The remainder of the study is organized as follows. Section 2 provides the background necessary to establish the main research question. Section 3 discusses the research design while the sample and data are described in Section 4. The results of the empirical analyses are reported in Section 5. Section 6 provides concluding remarks.

\section{Literature Review and Development of Hypotheses}

Auditor independence affects cost of capital in two ways. First, greater independence leads to better monitoring of the firm's net assets by the external auditors and higher rates of fraud discovery (DeAngelo, 1981). Better monitoring by auditors allows investors to forgo their own costly monitoring activities aimed at reducing the risk of expropriation on part of managers. This reduces the cost of capital and increases the price investors are willing to pay for the firm's securities. Consistent with this argument, Ashbaugh and Warfiled (2003) document a positive association between the selection of auditors with better monitoring skills and corporate debt levels in Germany. Second, independent auditors increase the credibility of reported figures and hence reduce the information asymmetry between investors and managers, which in turn reduces investment risk and cost of capital. Consistent with this argument, Pitman and Fortin (2004) find that large auditors provide better monitoring, which restricts earnings management and increases earnings quality. Botosan (1997) finds that the amount of information in financial statements is inversely related to measures of cost of equity capital. Hail (2002) finds that in Switzerland, 
where managers have considerable reporting discretion, measures of voluntary disclosure are inversely related to the ex-ante cost of capital. Yu (2005) extends Botosan's (1997) findings to debt markets.

We present a model (see Appendix) where the level of auditor independence is determined by profit-maximizing auditors who trade off additional fees (for instance in the form of NAS) for lower independence, with likely litigation cost and loss of reputation (Palmrose, 1988). It is assumed that greater independence improves reporting quality, monitoring and fraud detection. Consequently, the resulting relationship between auditor independence and cost of capital is negative; however, the magnitude of this relationship varies with the level of independence (i.e., non-linear relationship). We show that $S O X$ may increase or decrease this magnitude, depending on certain parameter values. We define certain conditions under which this magnitude increases with auditor independence. Specifically, this will be the case if the precision of financial reporting is sufficiently sensitive to changes in auditor independence. If $S O X$ resulted in an increase in the optimal level of auditor independence, we expect a stronger negative relationship between cost of capital and auditor independence after SOX.

We later provide evidence consistent with SOX increasing auditor independence. In addition, Cohen et al. (2008) provide evidence that reporting quality increased after SOX (as measured by a decline in earnings management). Taken together, these empirical findings suggest a calibration of our model under which financial reporting is quite sensitive to changes in auditor independence and, hence, a stronger negative association between auditor independence and cost of debt capital following SOX. However, as we discuss below, these latter observations aside, the literature on $S O X$ is yet undecided on its likely effects. 
SOX was enacted in order to fix auditing, particularly auditor independence, in the U.S. (Coates, 2007). To enhance auditor independence SOX requires a variety of mechanisms that directly aim at enhancing external monitoring activities through improving internal control procedures and placing more responsibility on the internal audit committee. The Act has also introduced greater costs for audit failures through the establishment of the $P C A O B$, whose role is "to protect investors and the public interest by promoting informative, fair, and independent audit reports". ${ }^{2}$ In addition, new regulations bar certain non-audit services $(N A S)$ and require fee disclosures. The regulators' presumption is that the removal of $N A S$, the disclosure requirements and the overall strengthening of the external auditor's position should result in greater auditor independence. $^{3}$

Still, some argue (e.g., Ribstein, 2002; DeFond and Francis, 2005) that $S O X$ is too costly and potentially ineffective. It is also possible that fees lost because of restrictions on NAS were recovered by charging higher audit fees, as auditors passed on to clients any cost they have incurred after SOX. Moreover, Coates (2007) argues that SOX made relatively small changes to already existing rules governing NAS. In addition, it has been argued that SOX may have resulted in a better alignment of shareholders' interests with that of managers, which can come at the expense of lenders (DeFond et al., 2007). The benefit of improved independence, if any, may thus accrue to shareholders and lenders will not be able to reduce cost of capital.

Given these conflicting arguments, we therefore ask: Has the passage of $S O X$ enhanced auditor independence and has it affected the association between auditor independence and the cost of debt capital? To the extent that $S O X$ has enhanced auditor independence, this should lead to more effective monitoring activities and the supply of higher quality information. If lenders have benefitted from better auditor independence, we would expect to see stronger relationship 
between auditor independence and cost of capital following SOX.

\section{Research Design}

The sample period is $2000-2006$. To be classified as Pre (Post) - SOX observation, a new bond issue must take place before (after) 30 July 2002, the date $S O X$ was signed into law. Each bond issue is matched with the most recently available annual report. We assume that annual reports become available within three months from fiscal year-end. For example, a bond issued on 15 April 2002 for a company with 31 December fiscal year-end is matched with the annual report data provided by Compustat for the year ended 31 December 2001 (Compustat item FYR $=2001)$.

Auditor independence is measured in two ways. The first is the ratio of audit fees to total fees $(R A U D)$. A higher RAUD implies lower economic bond, because the proportion of $N A S$ services is lower. However, audit and non-audit fees paid by an individual client may be affected by a variety of firm characteristics, auditor-specific factors and, in our sample period, by time trend due to structural changes in the audit market after $S O X$. For example, firms characterized by high business risk or complex mergers and acquisition activity are likely to experience higher audit fees. For such firms $R A U D$ may incorrectly indicate lower economic bond. Kinney and Libby (2002) argue that independence should be measured with respect to the component of fees that is unexplained by these factors. Accordingly, we construct a model that explains the level of $R A U D$ and use regression residuals to construct a measure of unexpected RAUD, denoted as UNEXPRAUD, where higher UNEXPRAUD signifies more independence. The second measure is based on the unexpected element in log of total fees (UNEXPLTFEE) for similar reasons. Log of total fees (LTFEE), in contrast to RAUD, is sensitive to scaling effects, 
and may provide a better reflection of the importance of a client to the auditor's business (Ashbaugh et al., 2003; Francis, 2006). Note that higher UNEXPLTFEE signifies less independence.

To measure the unexpected components of RAUD and LTFEE, we use a model similar to the one in Frankel et al. (2002) and Ruddock et al. (2006). Specifically, fees paid to the auditor are a function of a number of firm-specific factors (e.g., financial performance, leverage, market-to-book and growth), auditor-specific factors (e.g., Big-4 indicator, tenure and whether the auditor has been recently replaced), as well as task-complexity factors (e.g., size, and number of business segments). We also include a proxy for litigation risk, which may affect fees. Specifically, the full model, estimated on an annual basis is:

$$
\begin{aligned}
& D_{E P E N D} D_{i j}=\alpha+\beta_{1} R O A_{i}+\beta_{2} \text { LOSS }_{i}+\beta_{3} M_{R E T_{i}}+\beta_{4} C F O_{i}+\beta_{5} L E V_{i}
\end{aligned}
$$

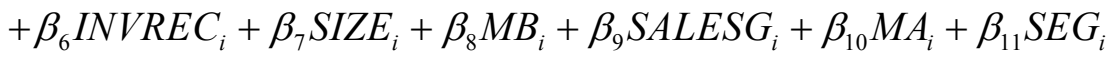

$$
\begin{aligned}
& +\beta_{12} A U D D U M_{j}+\beta_{13} \text { TENU }_{i j}+\beta_{14} \text { SWITCH }_{i j}+\beta_{15} L I T_{i}+v_{i}
\end{aligned}
$$

Where: $D E P E N D_{i j}=\left\{R A U D_{i j}, L T F E E_{i j}\right\}$ is a measure of the economic dependence between a client $i$ and an audit firm $j$. Independent variables that capture client performance and general audit risk are defined as follows: $R O A_{i}$ denotes return on assets, measured as net income divided by total assets; $\operatorname{LOSS}_{i}$ is an indicator variable equals to "1" if the firm reported a net loss in the current fiscal year, and "0" otherwise; $M R E T_{i}$ is market adjusted annual stock return (measured over the last 12 months of the reporting period); $C F O_{i}$ denotes cash flows from operations divided by total assets; $L E V_{i}$ denotes leverage ratio, measured as long-term debt divided by total assets. The proxies for task complexity are: $I N V R E C_{i}$ is equal to inventory plus accounts receivable divided by total assets; $S I Z E_{i}$ denotes firm size, measured as the natural logarithm of 
one plus total assets; $M B_{i}$ is the market-to-book ratio, measured as market value of equity divided by book value of equity; $S A L E S G_{i}$ is sales growth, measured as average percentage change in sales over the last three years; $M A_{i}$ is an indicator variable equals to "1" if the firm is involved in merger and acquisition activities in the current year, and "0"; $S E G_{i}$ is the number of the firm's business segments. Variables that capture auditor characteristics include: $A U D D U M_{j}$ is an indicator variable equals to " $1 "$ if the auditor is a Big-4 firm, and "0" otherwise. This variable captures the perceived quality of the auditor. $T E N U_{i j}$ is the natural logarithm of [one plus the number of years the firm has been consistently audited by the current auditor, as of the bond issuance date and based on Compustat]. This variable is a proxy for degree of familiarity with the auditee. SWITCH is an indicator variable, equal to "1" if a bond-issuing firm switches to a different audit firm in the fiscal year prior to the bond issuance, and " 0 " otherwise. It is included because firms may engage in opinion shopping which may lead to an effect on fees paid to the new auditor (Lennox, 2000). Finally, $L I T_{i}$ is a proxy for litigation risk, measured as the standard deviation of monthly stock return for the past 36 months (Francis et al., 1994).

We estimate Equation (1) for each year with industry fixed effects according to Fama and French's 12-industry classification. Then, we compute the unexpected components of RAUD and LTFEE as the regression residual. Positive (negative) UNEXPRAUD indicates greater (lower) independence. To simplify the reading of our results, we reverse the sign of residual form the LTFEE regression, so as to obtain a similar ordering whereby a positive residual indicates high level of independence while a negative residual signifies low level of independence.

Consistent with Ziebart and Reiter (1992) and Shi (2003), we use bond rating assigned by credit rating agencies and bond yield spread to capture the cost of borrowing. We construct one equation where bond rating $($ RATING) is the dependent variable and a second equation where 
bond yield spread (SPREAD) is the dependent variable. Though we are particularly interested in the association between auditor independence, the main variable of interest, and bond ratings and yield spread, we control for a number of factors that prior studies (e.g., Ziebart and Reiter, 1992; and Mansi et al., 2004) have identified to be associated with the cost of borrowing. Specifically, the basic bond rating equations contain the following components:

$$
\begin{aligned}
& \text { RATING }_{i}=\alpha+\beta_{1}{I N D E P_{i j}}+\beta_{2} \operatorname{ISIZE}_{i}+\beta_{3} \operatorname{SIZE}_{i}+\beta_{4} L E V_{i}+\beta_{5} O_{\text {OSCORE }} \\
& +\beta_{6} \mathrm{COVR}_{i}+\beta_{7} \mathrm{ROA}_{i}+\beta_{8} L I T_{i}+v_{i} \\
& S P R E A D_{i}=\alpha+\beta_{1}{I N D E P_{i j}}_{i j} \beta_{2} \text { RATING }_{i}+\beta_{3} \operatorname{ISIZE}_{i}+\beta_{4} \operatorname{SIZE}_{i}+\beta_{5} L E V_{i} \\
& +\beta_{6} \mathrm{OSCORE}_{i}+\beta_{7} \mathrm{COVR}_{i}+\beta_{8} \mathrm{ROA}_{i}+\beta_{9} L I T_{i}+v_{i}
\end{aligned}
$$

Bond ratings are coded as integers ranging from 1 (Aaa) to 22 (D) based on Moody's categorical bond rating (higher integer value implies worse rating). Yield spread is defined as the difference in percentage points between the yield to maturity for the corporate debt and the yield on a United States treasury bond with comparable maturity on the issuance date. Higher spread thus implies higher cost of debt capital. That is, yield spread is unaffected by the level of the risk-free rate.

The coefficient $\beta_{1}$ on INDEP $P_{i t}$ captures the effect of auditor independence on bond ratings and yield spread. Consistent with the theoretical model, greater independence leads to lower cost of capital, implying that the coefficients $\beta_{1}$ in equations (2a) and (2b) are expected to be negative. We use the following control variables in our regression models: $I S I Z E_{i}$ denotes the relative size of the debt issue, measured as the total principal amount of debt issue divided by the firm's total assets. Large debt issue means higher probability of default and therefore is 
expected to be positively related to the cost of borrowing (Sengupta, 1998). SIZE $E_{i}$ is firm size, as defined before. Ceteris paribus, larger firms are more diversified and less risky, hence are expected to have better bond ratings and lower bond yield premium. $L E V_{i}$ is a leverage ratio as defined above. Higher leverage ratios are associated with lower ratings (higher assigned integers) and higher bond yield premium, because leverage is associated with financial risk. $\mathrm{OSCORE}_{i}$ is a measure of bankruptcy risk, measured as Ohlson's (1980) score. This score captures likelihood of bankruptcy that may not be captured by other variables and is expected to be negatively related to bond rating and the cost of borrowing. COVR $R_{i}$ is the firm's interest coverage ratio, measured as operating income divided by interest expenses. This variable captures the ability of the borrowing firm to make regular interest payment. We thus expect higher coverage ratio to be positively (negatively) related to ratings (bond yield premium). $R O A_{i}$ is operating profitability, as defined above. Consistent with Shi (2003), we expect higher profitability to be positively (negatively) related to ratings (bond yield spread). Finally, $L I T_{i}$ is a measure of litigation risk, as defined before. This risk measure is expected to be associated with lower rating and higher cost of borrowing.

The bond yield spread equation also includes bond ratings (RATING) as an explanatory variable. Rating agencies (e.g., Moody's) assess default probabilities, which are used by investors, together with other information (e.g., auditor independence) to price bonds. As investors likely observe the rating agencies' reports and use these as inputs into their own models in addition to their private information, we use RATING as a proxy for investors' own assessment of default probability. Consequently, the other coefficients in Equation ( $2 \mathrm{~b}$ ) capture any incremental effect on the bond yield spread of investors' beliefs after controlling for the information already reflected in ratings. 
The focus of the main tests is whether the coefficients $\beta_{1}$ in equations (2a) and (2b) changed around the enactment of SOX. To facilitate these tests, we define an indicator variable, $S O X$, which is set equal to " 1 " during the post-SOX period, and " 0 " otherwise. To the extent that SOX has increased auditor independence and consequently resulted in reduction in cost of capital, the difference of the coefficient on INDEP is expected to be negative and significant. Absence such an effect, or to the extent that bondholders are worse off because of the effect of SOX on auditor independence, we would expect a non-negative difference.

\section{Sample and Descriptive Statistics}

To estimate Equation (1) we employ a dataset based on the intersection of Compustat and Audit-Analytics. The Audit-Analytics database provides data for public firms about auditor independence characteristics, including the client-level audit/non-audit fees, auditor-level audit/non-audit fees, and other variables. This procedure results in 21,773 firm/year observations suitable for estimating Equation (1). In this analysis, we use a larger sample than the sample of bond issuers that will be used for the main analysis. This is because we are interested in measuring auditor independence for the entire population and not only for bond issuers to avoid bias in these measures. This procedure also furnishes more power to capture structural changes following SOX. The estimation of the RAUD regression employs the quasilikelihood method (Papke and Wooldridge, 1996) since the dependent variable ranges between zero and one. The regression results for $R A U D$ are presented in Table 1, Panel A, whereas the regression results for $L T F E E$ are presented in Panel B of this table.

Analyzing this sample (results not tabulated) shows that mean (median) RAUD increases, at the 0.01 level, from $0.43(0.42)$ before $S O X$ to $0.66(0.70)$ after $S O X$. Also, mean (median) 
LTFEE decreases, at the 0.01 level, from 13.58 (13.58) before SOX to 13.24 (13.07) after SOX. These findings are consistent with an increase in auditor independence following the enactment of $S O X$.

Focusing on panel A, several variables exhibit consistent association with $R A U D$. The coefficients on LOSS (negative income indicator) are positive and significant at the 0.10 level or better in four of the seven years examined, suggesting that audit fees are higher for loss-making firms, consistent with higher audit and reputation risks. Companies with higher cash flows consume less audit services relative to total services, as reflected by the negative coefficients on $C F O$ (significant at the 0.10 level or better in five of the seven years reported). Firm size (SIZE) is negatively (at the 0.05 level or better in all years) related to $R A U D$, as expected, suggesting that larger firms pay relatively more non-audit fees. Firms with higher market-to-book ratios tend to pay more for NAS. Companies engaging in $M \& A$ activities tend to increase NAS, as reflected by the negative coefficients on $M A$ (significant at the 0.05 level or better in five out of seven years). Auditor size ( $A U D D U M$ ) is negatively related to $R A U D$ in $2000-2002$, but this relation reverses in 2004-2006. This suggests that in more recent years large auditors provide relatively more audit than non-audit services. This is explained, at least in part, by the effect of $S O X$ and the collapse of Arthur-Andersen. Risk of litigation (LIT) is positively related to RAUD, suggesting that auditors spend relatively more effort on the audit task in the presence of litigation risk. The remaining variables exhibit sporadic relation with $R A U D$ obtaining significant coefficients in certain periods but not in others. Using the results in panel A, we use the regression residuals as a measure of unexpected $R A U D$ and denote it UNEXPRAUD.

Turning to Panel $\mathrm{B}$, all seven coefficients on $R O A$ are negative, as expected, and significant at the 0.01 level suggesting that profitable firms' total fees to auditors are lower. 
Firms with relatively larger inventories and receivables consume relatively more services, as reflected by the positive coefficients on INVREC (significant at the 0.01 level in all years). Also, as expected, larger firms consume more services from audit firms, as reflected by the positive and significant coefficients on SIZE. Firms characterized by high market-to-book ratios pay more to audit firms due to the presence of more intangibles, which may be associated with the demand for special services from the audit firm. Engaging in mergers and acquisition activities and having more business segments require more services from the audit firms, as indicated by the positive coefficients on $M A$ and $S E G$ (generally significant at the 0.05 level or better).

Larger audit firms are more "expensive" than smaller ones, as suggested by the positive coefficients on $A U D D U M$. Also, since 2002 longer client-auditor relationship are associated with larger total fees, as reflected by the positive coefficients on TENU. In contrast, companies that switch auditors pay less total fees to the new audit firm, consistent with low balling by new auditors. As expected, companies exposed to higher litigation risk pay more to the audit firms (coefficients on LIT are positive and significant at the 0.05 level or better in 2002-2006). The remaining variables (LOSS, MRET, CFO, and $L E V$ ) exhibit weak or sporadic association with total fees, perhaps due to the correlation with other explanatory variables. Using the results in panel B, we compute the unexpected levels of total fees, reverse its sign, and denote it UNEXPLTFEE.

We also estimated Equation (1) using a pooled fixed-effects model. We find that yearly intercepts in the RAUD regression monotonically increase over time (not tabulated). In particular, the regression intercept in 2001 is 0.10 larger than that in 2000. Similarly, the regression intercepts increase by $0.40,0.71,1.16,1.52$ and 1.63 in 2002, 2003, 2004, 2005 and 2006, respectively (all at the 0.01 level). This behaviour is consistent with higher auditor 
independence after SOX. Similarly, we find (results not tabulated) that the yearly intercepts in the LTFEE regression are stable in 2000-2003 but there is an upward shift in 2004-2006 (significant at the 0.01 level). This pattern suggests an increase in total fees to the audit firm after $S O X$, which could be explained by the additional audit tasks imposed by it.

(Table 1 about here)

Our main sample is based on firms that issued bonds in the primary market. We use the Security Database Corporation (SDC) Platinum database to extract all information about new bond issues by US companies from June 1999 to September 2007, including non-convertible debt issues, convertible debt issues and mortgage $\&$ asset-backed debt issues. Bonds that are not rated by Moody's and those with maturities of one year or less are excluded from the sample. In addition, we exclude bonds issued by financial institutions (4-digit SIC codes 6000-6999) and public utilities (4-digit SIC codes 4900-4949) due to the different structure of their financial statements and regulatory environment. Bond issues that coincide with mergers, acquisitions or initial public offerings are removed from the analysis in order to mitigate the effect of confounding events.

The observations included in the final sample meet the following criteria: data on bond issuance characteristics are available on SDC; firms' financial data are available in Compustat; data on audit firms' characteristics, audit/non-audit fees are available on AA. The final sample consists of 1,802 bond issuances over seven fiscal years (2000-2006). ${ }^{4}$ Table 2, Panel A, summarizes the sample selection process.

Panel B of Table 2 presents the industry composition of the final sample based on the Fama-French (FF) 12-industry classification. The Table shows that a large number of bonds in the sample are issued by companies in the consumer durables industry (FF2), manufacturing 
(FF3), and chemicals and applied products (FF5), however, the composition of the observations exhibits no significant clustering of firms or industries. Furthermore, a large number of firms are involved in multiple bond issues (about five issues per firm, on average). We take account of this in the various analyses. Also, our empirical tests control for industry fixed effects based on this distribution.

\section{(Table 2 about here)}

Table 3 presents summary statistics for the variables used in the analysis. Panel A presents summary statistics for each variable in the Pre- and Post-SOX periods. In addition, we present results of univariate tests on the difference in means (t-test) and medians (Wilcoxon test). As panel A shows, mean (median) SPREAD increased from 1.55 (1.20) in the Pre-SOX period to 1.80 (1.60) in the Post-SOX period (significant at the 0.01 level). Similarly, means and median bond rating (RATING) increased following the enactment of SOX (significant at the 0.01 level). These results suggest that bonds have become more risky following the enactment of SOX. Panel A also shows that return on assets $(R O A)$, cash from operations $(C F O)$ and market-tobook ratios $(M B)$ decreased subsequent to the enactment of SOX. This reduction in firm profitability is consistent with the increase in bond risk.

Audit fees account for $39 \%$ of total fees (mean $R A U D=0.39$ ) in the Pre-SOX period, increasing to $68 \%$ (mean $R A U D=0.68$ ) following $S O X$ (difference is significant at the 0.01 level), consistent with new restrictions on NAS. Total fees are smaller in the post-SOX period, suggesting auditors have not been able to recoup lost NAS fees through higher audit fees. Looking at other audit independence variables, we observe an increase in the level of auditor independence following the enactment of $S O X$ (significant at the 0.01 level). For instance, the mean for UNEXPRAUD decreases from 0.18 to 0.10 (significant at the 0.01 level) implying that 
the level of independence has increased. Also, the mean of UNEXPLTFEE decreased from - 0.04 in the Pre-SOX period to -0.19 in the post-SOX period (significant at the 0.01 level). Note that this variable is negative owing to the multiplication of the regression residual by -1 .

Panel B shows a significant increase in RAUD from 2002 onward, indicating that restrictions on the provision of $N A S$ have been quite effective and auditors have become more independent after SOX. In particular, whereas only $33 \%$ of total fees were paid in 2000-2001 for audit services, by 2005 this figure has increased to $78 \%$. This indicates a structural shift in the market for services provided by external auditors following SOX. The Panel also shows a decline in log of total fees (LTFEE), consistent with an increase in overall auditor independence.

(Table 3 about here)

Table 4 presents Pearson (above diagonal) and Spearman (below diagonal) correlations for selected variables in our analysis. Bond yield spread (SPREAD) and bond ratings (RATING) are highly correlated $($ Pearson $=0.70$; Spearman $=0.71)$, as bond rating is an important factor in determining the yield spread. Yet, this also implies other factors are taken into account by bond investors in addition to the rating. Also, the independence measures are correlated. For example, the Pearson (Spearman) correlation between UNEXPRAUD and UNEXPLTFEE is $-0.32(-0.39)$. In addition, the independence measures are correlated with RATING and SPREAD, as expected.

(Table 4 about here)

\section{Empirical Results}

Table 5 presents the results for the regressions in which bond rating and yield spread are the dependent variables and UNEXPRAUD is the measure of auditor independence. The left three columns present the results for bond ratings and the right-most three columns present the 
results for the yield spread regressions. Starting with the bond rating analysis, the coefficients on UNEXPRAUD are negative both before $\operatorname{SOX}(-1.25, t=-3.03)$ and after $\operatorname{SOX}(-1.64, t=-3.18)$, implying that greater auditor independence is associated with better bond ratings for both periods examined. The difference between the two coefficients is -0.39 and is statistically significant at the 0.05 level.

As for the control variables, bond ratings are more sensitive to the interest coverage ratio $(C O V R)$ profitability $(R O A)$ and litigation risk $(L I T)$ in the post-SOX period. The coefficient on the $S O X$ indicator variable is positive but not significantly different from zero at the 0.10 level. This last result suggests no direct effect of $S O X$ on bond ratings.

The analysis of the yield spread, reported in the last three columns, reveals no statistically significant association with $U N E X P R A U D$ in the pre-SOX period. In contrast, the coefficient on UNEXPRAUD in the post-SOX is negative and significantly different from zero at the 0.05 level $(-0.26, t=-2.23)$. The difference between the two coefficients is -0.30 and is statistically significant at the 0.05 level. This result suggests that the negative association between the cost of borrowing and auditor independence has become stronger after the enactment of SOX.

Regarding the control variables, all the controls, except ISIZE are statistically significant in both periods. We find that the yield spread is less sensitive to issue size (ISIZE) and more sensitive to issuer size (SIZE) following $S O X$ (both at the 0.05 level). All other control variables do not exhibit different association with yield spread following SOX. In addition, the coefficient on the $S O X$ indicator variable is negative and significantly different from zero at the 0.05 level ($0.32, t=-2.40$ ), suggesting that, on average, yield spread decreased after the enactment of SOX. Note that this is in contrast to the findings of the univariate analysis reported in Table 3 . This is broadly consistent with some of the Act's provisions having a direct effect of reducing cost of 
debt capital. The model explanatory power is high, as reflected by $R^{2}$ s ranging between 0.62 and 0.74 across the six regressions.

Overall, the results so far are consistent with improvement in auditor independence (Table 3) and that auditor independence, as measured by UNEXPRAUD, is more inversely related to the cost of debt capital in the post-SOX period (Table 5). The results also suggest that after controlling for several economic factors, including auditor independence, the average yield spread has declined following SOX. The average reduction in yield spread following SOX should be viewed as a direct economic benefit of the Act.

(Table 5 about here)

Table 6 is similar in structure to Table 5, but utilizes UNEXPLTFEE as the measure of auditor independence. Starting with the bond rating analysis, the coefficient on UNEXPLTFEE in the pre-SOX period is negative and statistically significant at the 0.10 level. In the post-SOX period this coefficient is more negative and the difference between the two coefficients is negative and statistically significant at the 0.05 level $(-0.17, t=-2.42)$. This result confirms that the association between bond ratings and auditor independence has become stronger following SOX.

Similar to Table 5, all the control variables are statistically significant at the 0.05 level or better in both periods. Also, bond ratings are more sensitive to the interest coverage ratio $(C O V R)$ profitability $(R O A)$ and litigation risk $(L I T)$ in the post-SOX period. The coefficient on the $S O X$ indicator variable is, once again, positive but not significantly different from zero at the 0.10 level.

When SPREAD is the dependent variable, the results are qualitatively similar to those reported in Table 5. In particular, the independence measure is negatively related to the yield 
spread in both periods and the difference between the two coefficients is negative and statistically significant at the 0.05 level $(-0.15, t=-2.20)$. This result suggests a stronger negative relationship with cost of debt capital following $S O X$. Also, the coefficient on the SOX indicator variable is negative and significantly different zero at the 0.05 level $(-0.36, t=-2.57)$, suggesting that, on average, yield spread decreased after the enactment of SOX.

Overall, the results in Tables 3, 5 and 6 are consistent with SOX improving auditor independence and that following the Act the negative association between auditor independence and cost of debt capital is stronger. This suggests that auditor independence is priced by lenders to a greater extent after $S O X$ than before, consistent with auditor independence becoming more credible for monitoring and reporting purposes after $S O X$.

(Table 6 about here)

We carry out a number of sensitivity tests. First, because the measure of the unexpected component in Equation (1) may be sensitive to the model specification, we use the raw level of $R A U D$ as a third measure of independence. The regression results involving this variable are reported in Table 7 . The bond rating analysis shows that in both sub periods, the coefficient on RAUD is negative and significant at the 0.05 level, or better. The difference is negative, as expected, but not statistically significant at the 0.10 level. The analysis of yield spread shows a negative and significant coefficient on $R A U D$ in both the pre-SOX and the post-SOX periods. The difference of -0.44 between these coefficient is significant at the 0.01 level suggesting that the association between the cost of borrowing and auditor independence has become stronger following $S O X$. In addition, the coefficient on the $S O X$ indicator variable is negative $(-0.28, \mathrm{t}=-$ 2.26) and significant at the 0.05 level suggesting, as in tables 5 and 6 , that after controlling for 
auditor independence and other relevant factors, yield spread decreased following the enactment of $S O X$.

(Table 7 about here)

A potential explanation for these findings is that companies that issued debt in the post$S O X$ period are fundamentally different from those that issued debt in the pre-SOX period and that these fundamental differences are not adequately captured by our control variables. To remove any fixed firm effects, we repeat the analysis using only companies that issued debt both in the pre- and the post-SOX periods. This way, firm-specific cross-sectional differences among sample firms are controlled for, although it is still possible, but less likely, that fundamental differences exist in the same set of firms in two different sub-periods.

Table 8 presents summary results for the re-estimation of Tables 5-7 for companies that issued bonds in both sub-periods. This set contains data for 165 companies with 442 issues in the pre-SOX period and 748 issues in the post-SOX period. For brevity, we report only the coefficients on the auditor independence variables and the $S O X$ indicator variable where panels A, B and C, correspond to Tables 5, 6 and 7, respectively.

When UNEXPRAUD is the auditor independence measure, the difference in the coefficients between the pre- and post-SOX periods is negative, as expected, and statistically significant at the 0.01 level for both the bond rating and the yield spread regressions. When UNEXPLTFEE and RAUD serve as the independence measures, the coefficient on the independence variable is more negative in the post-SOX period than in the pre-SOX period. The differences between the pre- and post-SOX coefficients are negative, as expected, in all cases. However, these differences are significant at the 0.05 level or better in the yield spread regressions but not in the bond rating regressions. Regarding the coefficients on the SOX 
indicator variable, these are negative and significant at the 0.05 level in the yield spread regressions. Overall, results in Table 8 are consistent with those reported in Tables 5-7 suggesting that firm fixed-effects are not driving our results.

(Table 8 about here)

We conducted several additional robustness checks. Since SPREAD, is a bounded dependent variable, we re-estimate the yield spread regressions in Tables 5-7 using lognormal transformation of the dependent variable to check the sensitivity of our findings to the normality assumption. Specifically, we compute the natural logarithm of one plus SPREAD and use it as the dependent variable in Equation (2). We find that the coefficients on UNEXPRAUD, UNEXPLTFEE and RAUD are more negative and statistically significant in the post-SOX period than in the pre-SOX period and that the difference is statistically significant at the 0.10 level or better in all three cases. Thus, the fact that $S P R E A D$ is a bounded dependent variable does not affect our inferences.

Second, we also check the robustness of the main findings to the choice of mid 2002 as a cutoff point for the pre- and post-SOX periods. The implementation of the SOX Act has not been instantaneous as Congress left for the SEC to set the precise rules for certain sections of the Act. Thus, the full effect of SOX has been felt perhaps months after July 2002. On the other hand, consistent with our original cutoff point, it is plausible that companies have started to react to the new law even before the specific rules and the effective day were set for the various sections of the Act. We therefore replicate the analyses in Tales 5-7 by selecting 30 July 2003 as an alternative cutoff point. Bond issuances that took place after this date are classified as post-SOX. The results (not tabulated) are very similar to those reported in Tables 5-7 and all the statistical inferences hold as before. 
Third, the inclusion of multiple issues by the same firm raises a concern regarding the over-estimation of the previous models. To address this concern, we estimate our equations using a reduced sample. In particular, if a firm issues multiple bonds in the same fiscal year, then only the first issue is used in the sample. This sampling process results in a reduced sample of 209 pre-SOX and 493 post-SOX firm/year observations. The results based on the reduced sample (not tabulated) are very similar to those reported in Tables 5-7. In particular, the difference in the coefficients on the independence measures UNEXPRAUD and UNEXPLTFEE are negative and statistically significant at the 0.10 level or better in both the bond rating and yield spread regressions. However, the difference in $R A U D$ is statistically significant only in the yield spread regression. ${ }^{5}$

Our analysis identifies an inter-temporal change in the association between auditor independence and the cost of borrowing. It could be that other unidentified factors, unrelated to SOX, affect that inter-temporal relation. To address this concern we repeated our analysis using fiscal 2004 as an arbitrary cut-off point. Specifically, we divided the Post-SOX period into two periods: The period starting from the enactment of SOX and until the end of fiscal 2003 (Pre2004), and the period starting after fiscal 2004 and ending in fiscal 2006 (Post-2004). If what we capture is simply the result of a secular trend over time, we would expect to replicate the previous findings using this arbitrary cutoff point. However, we find that the association between auditor independence and cost of borrowing is not different across these two periods. Overall, these sensitivity tests provide additional evidence in support of the argument that the relationship between auditor independence and cost of borrowing has changed following the enactment of SOX. 


\section{Summary}

We investigate whether the negative association between auditor independence and the cost of borrowing, measured here as bond rating and yield spread, has become stronger following the enactment of SOX. This is an important and relevant issue as SOX and related regulation have been criticized for high implementation costs with little or no benefits. We offer a theoretical model in which cost of capital is inversely related to auditor independence. The model predicts that if SOX has been successful at enhancing auditor independence, and if reporting quality is sufficiently sensitive to auditor independence, we would expect to find stronger association between auditor independence and cost of debt capital in the period following the enactment. Our empirical findings are consistent with this prediction and are robust to changes in model specification, variable measurement and estimation methods.

Nevertheless, our research design suffers from at least one caveat. It is possible that our findings are driven by a change in investors' and credit rating agencies' perceptions of the "value relevance" of auditor independence, rather the effect of $S O X$ itself on auditor independence. That is, to the extent that bond investors and credit rating agencies did not fully appreciate the role of auditor independence as an effective mechanism prior to recent accounting scandals and the subsequent change in the regulatory landscape, they failed to take into account audit independence before the enactment of SOX. This may be what we capture, rather than the effectiveness of $S O X$ per se. 


\section{References}

Ashbaugh, H., R. LaFond, and B.W. Mayhew. 2003. Do Non-audit Services Compromise Auditor Independence? Further Evidence. The Accounting Review, vol. 78 (3), pp. 611-639.

Ashbaugh, H., and T. D. Warfield. 2003. Audits as a Corporate Governance Mechanism: Evidence from the German Market. Journal of International Accounting Research, vol. 2, pp. 1-21.

Botosan, C. A. 1997. Disclosure Level and the Cost of Equity Capital. The Accounting Review, vol. 72, pp. 323-349.

Brandon, D. M., A. D. Crabtree, and J. J. Maher. 2004. Non-Audit Fees, Auditor Independence, and Bond Ratings. Auditing: A Journal of Practice and Theory, vol. 23, pp. 89-103.

Coates, J. 2007. The goals and promise of the Sarbanes-Oxley Act. Journal of Economic Perspectives, vol. 21, pp. 91-116.

Cohen, D. A., A. Dey and T. Z. Lys. 2008. Real and Accrual-Based Earnings Management in the Pre- and Post-Sarbanes-Oxley Periods. The Accounting Review, vol. 83 (3), pp. 757-787.

DeAngelo, L. 1981. Auditor Size and Audit Quality. Journal of Accounting and Economics, vol. 3, pp. 183-199.

DeFond, M., K. Raghunandan and K.R. Subramanyam. 2002. Do Non-Audit Service Fees Impair Auditor Independence? Evidence from Going Concern Audit Opinions. Journal of Accounting Research, vol. 40, pp. 1247-1274.

DeFond, M., and J. Francis. 2005. Audit Research after Sarbanes-Oxley. Auditing: A Journal of Practice \& Theory, vol. 24 (Supplement), pp.5-30.

DeFond, M., M. Hung, E. Karaoglu and J. Zhang. 2008. Was the Sarbanes-Oxley Act good news for corporate bondholders? Working Paper, University of Southern California.

Dhaliwal, D., C. A. Gleason, S. Heitzman and K. D. Melendrez. 2008. Auditor Fees and Cost of Debt. Journal of Accounting, Auditing and Finance, vol. 23 (1) pp. 1-22.

Dye, R. A. 2001. An Evaluation of 'Essays on Disclosure' and the Disclosure Literature in Accounting. Journal of Accounting and Economics, vol. 32, pp. 181-235.

Easley, D. and M. O'Hara. 2004. Information and the Cost of Capital. Journal of Finance, vol. 59 pp. $1553-1584$.

Francis, J. 2006. Are Auditors Compromised by Nonaudit Services? Assessing the Evidence. Contemporary Accounting Research Vol. 23 (3), pp. 747-60 
Francis, J., D. Philbrick, and K. Schipper. 1994. Determinants and Outcomes in Class Action Securities Litigation. Working Paper, University of Chicago.

Frankel., R., M. Johnson, and K. Nelson. 2002. The Relation between Auditors' Fees for NonAudit Services and Earnings Management. The Accounting Review, vol. 77 (Supplement), pp. 71-105.

Gietzmann M. and J. Ireland. 2005. Cost of capital, Strategic Disclosure and Accounting Choice. Journal of Business Finance \& Accounting, vol. 32 (3\&4), pp. 599-634.

Hail, L. 2002. The Impact of Voluntary Corporate Disclosure on the ex-Ante Cost of Capital for Swiss Firms. European Accounting Review, vol. 11 (4) pp. 741-773.

Kinney W and R Libby. 2002. Discussion of the Relation between Auditors' Fees for Nonaudit Services and Earnings Management. The Accounting Review, vol. 77 (Supplement), pp. 107-114.

Kinney, W. R., Z. Palmrose, and S. Scholz. 2004. Auditor Independence, Non-Audit Services, and Restatements: Was the U.S. Government Right? Journal of Accounting Research, vol. 42, pp. 561-588.

Khurana, I, and K. Raman. 2006. Do Investors Care about the Auditor's Economic Dependence on the Client? Contemporary Accounting Research, vol. 23, pp. 977-1016

Lennox, C. 2000. Do Companies Successfully Engage in Opinion Shopping? Evidence from the UK. Journal of Accounting and Economics, vol. 29, pp. 321-339.

Levitt, A. 2000. Renewing the Covenants with Investors. Speech at the New York University Center or Law and Business, New York, May 10.

Mansi, S.A., W.F. Maxwell, and D.P. Miller. 2004. Does Auditor Quality and Tenure Matter to Investors? Evidence from the Bond Market. Journal of Accounting Research, vol. 42, pp. $755-793$.

Nikolaev, V. and L. Van Lent. 2005. The Endogeneity Bias in the Relation between Cost-ofDebt and Corporate Disclosure Policy. European Accounting Review, vol. 14 (4) pp. 677724.

Ohlson, J.A.1980. Financial Ratios and the Probabilistic Prediction of Bankruptcy. Journal of Accounting Research, vol. 18, pp. 109-131.

Palmrose, Z. 1988. An Analysis of Auditor Litigation and Audit Service Quality. The Accounting Review, vol. 63, pp. 55-73. 
Pany, K., and M.J. Reckers. 1983. Auditor Independence and Non-audit Services: Director Views and their Policy Implications. Journal of Accounting and Public Policy, vol. 2 (1), pp. 43-62.

Papke, L., and J. Wooldridge. 1996. Econometric methods for fractional response variables with an application to $401(\mathrm{~K})$ plan participation rates. Journal of Applied Econometrics 11, pp. 619-632.

Pitman, J.A., and S. Fortin. 2004. Auditor Choice and the Cost of Debt Capital for Newly Public Firms. Journal of Accounting and Economics, vol. 37, pp. 113-136.

Ribstein, L. E. 2002, "Market vs. regulatory responses to corporate fraud: A critique of the Sarbanes-Oxley Act of 2002," Journal of Corporation Law, vol. 28, 1-67.

Ruddock, C., S. Taylor, and S. Taylor. 2006. Nonaudit Services and Earnings Conservatism: Is Auditor Independence Impaired? Contemporary Accounting Research, vol. 23, pp. 701-746.

Sengupta, P. 1998. Corporate Disclosure Quality and the Cost of Debt. The Accounting Review, vol. 73, pp. 459-474.

Shi, C. 2003. On the Trade-off between the Future Benefits and Riskiness of R\&D: A Bondholders' Perspective. Journal of Accounting and Economics, vol. 35, pp. 227-254.

Verrecchia. R. E. 2002. Essays on Disclosure. Journal of Accounting and Economics, vol. 32, pp. 97-180.

White, H. 1980. A Heteroscedasticity-Consistent Covariance Matrix Estimator and a Direct Test for Heteroscedasticity. Econometrica, vol. 48, pp. 817-838.

Yu, F. 2005. Accounting Transparency and the Term Structure of Credit Spreads. Journal of Financial Economics, vol. 75, pp. 53-84.

Ziebart, D.A., and S.A. Reiter. 1992. Bond Ratings, Bond Yields and Financial Information. Contemporary Accounting Research, vol. 9, pp. 252-282. 


\section{Appendix - The Association between Auditor Independence and Cost of \\ Capital - A Theoretical Model}

\section{(1) Preliminaries}

Consider a single period competitive security market populated by risk-averse investors with negative exponential utility function of the form $u(x)=-\exp ^{-\rho x}$, where $\rho$ is the risk aversion parameter and $\mathrm{x}$ is each investor's final wealth. Without loss of generality, assume each investor can buy one security and that the risk-free rate is zero. If the investor buys one security, then $\mathrm{x}$ will be a function of the payoff on the security, which is assumed to be a normal random variable, $v$, where $v \sim \mathrm{N}\left(\mu_{0}, \sigma^{2}\right)$ and $\mu_{0}>0$. If the price of the security is $P$, then the investor's end of period wealth is $\mathrm{x}=v-P$. That is, the investor's final wealth is the profit on the investment. The expected utility under these assumptions is related to the expression:

$$
\rho[E(v)-P-1 / 2 \rho \operatorname{var}(v)]
$$

In equilibrium, $P$ is such that the expression in the square bracket is zero. If $P$ is too large, the expression in (A1) is negative, implying no one will be willing to buy the security. If $P$ is too small then expression (A1) is positive, however, investors in a competitive market will bid this price up. Therefore the equilibrium security price is given by

$$
P=E(v)-1 / 2 \rho \operatorname{var}(v)=\mu_{0}-1 / 2 \rho \sigma^{2}
$$

$P$ is increasing in the expected cash flow on the security, $\mu_{0}$, and is decreasing in the variability of the final cash flow, $\sigma^{2}$. The higher the risk of the security, the lower its price and the higher is the cost of capital. Therefore, a lower price is equivalent to higher cost of capital (captured here by the difference between $P$ and $\left.\mu_{0}\right)$. 


\section{(2) The role of financial reporting}

Financial disclosure is an informative signal about the security payoff. Denote this signal $S$ and let $S=\mathrm{v}+\varepsilon$, where $\varepsilon \sim N\left(0, \sigma_{\varepsilon}^{2}\right)$. The signal is assumed unbiased and a more informative financial disclosure involves a lower $\sigma_{\varepsilon}^{2}$. Given a particular realization of $S, P$ can be expressed as follows:

$$
P=E(v \mid S)-1 / 2 \rho \operatorname{var}(v \mid S)=\frac{\sigma_{\varepsilon}^{2}}{\sigma^{2}+\sigma_{\varepsilon}^{2}} \mu_{0}+\frac{\sigma^{2}}{\sigma^{2}+\sigma_{\varepsilon}^{2}} S-1 / 2 \rho \sigma^{2} \frac{\sigma_{\varepsilon}^{2}}{\sigma^{2}+\sigma_{\varepsilon}^{2}} .
$$

Integrating over all possible realizations of $S$, the expected equilibrium price is given by:

$$
E(P)=\mu_{0}-1 / 2 \rho \sigma^{2} \frac{\sigma_{\varepsilon}^{2}}{\sigma^{2}+\sigma_{\varepsilon}^{2}}
$$

$P$, on average, is negatively related to the signal's variance, $\sigma_{\varepsilon}^{2}$, which means that less accurate financial reporting increases the investment risk.

\section{(3) The link between auditor independence and the accuracy of financial reporting}

The production of accurate financial statements is assumed to be a function of auditor independence: lower auditor independence reduces the accuracy of the reports. Lower reporting accuracy is costly, as this could lead to loss of reputation, higher likelihood of SEC investigation, and litigation.

Let $h$ denote the variance of the report $S$, where $h \equiv \sigma_{\varepsilon}^{2}$. Assume $h(I)$ is any function such that $h^{\prime}(I)<0$ and $h^{\prime \prime}(I) \geq 0$. That is, higher independence results in lower $h$, or higher accuracy, but at a flat or decreasing rate (i.e., decreasing marginal effect). 


\section{(4) The link between auditor independence and monitoring}

Higher auditor independence is expected to improve the processes of monitoring and fraud detection. To capture this, assume any function $\mu(I)=\mu_{0}-f(I)$ such that, $f\left(I_{\text {min }}\right)>0$, $f\left(I_{\max }\right)=0$ and $f^{\prime}(I)<0$ implying $\mu^{\prime}(I)>0$. When auditor independence is at its highest possible level, fraud or expropriation by managers is zero and the security's expected cash flow is equal its original value $\mu_{0}$. But if the auditor reduces her independence, there will be a reduction in the effectiveness of monitoring, leading to a higher level of fraud, and hence, reduction in expected cash flows.

\section{(5) The effect of auditor independence on the cost of capital}

The cost of capital is lower when the auditor is more independent. To see that, rewrite Equation (A4) - the expected equilibrium price - as follows:

$$
E(P)=\mu(I)-1 / 2 \rho \sigma^{2} \frac{h(I)}{\sigma^{2}+h(I)}
$$

To see how $E(P)$ changes with $I$, differentiate Equation (A5) with respect to $I$. Because the slope coefficient in the regression of the security price on auditor independence, $\beta$, is this derivative:

$$
\beta \equiv \frac{d E(P)}{d I}=\mu^{\prime}(I)-1 / 2 \rho \sigma^{4} \frac{h^{\prime}(I)}{\left(\sigma^{2}+h(I)\right)^{2}}>0
$$

The positive relation is the consequence of two effects of the auditor independence: (i) the effect of improving the accuracy of the accounting report and thereby reducing the investment risk, as $h^{\prime}(I)<0$, and (ii) the effect of preventing fraud and waste through monitoring as $\mu^{\prime}(I)>0$. The former effect on the cost of capital is present when investors are risk-averse. On the other hand, the latter effect influences the price independently of the market's degree of risk aversion. 
Since $E(P)$ increases in $I$, it follows that the expected cost of capital is decreasing in auditor independence. However, note that $\beta$ is not a constant with respect to $I$. Specifically,

$$
\frac{d \beta}{d I}=\mu^{\prime \prime}(I)+1 / 2 \rho \sigma^{4} \frac{2 h^{\prime}(I)^{2}-h^{\prime \prime}(I)\left(\sigma^{2}+h(I)\right)}{\left(\sigma^{2}+h(I)\right)^{3}}
$$

The magnitude of the negative association between cost of capital and auditor independence is stronger (weaker) if Equation (A7) is positive (negative). Specifically, if the variance of the signal is sufficiently sensitive to auditor independence (i.e., when $h^{\prime}(I)^{2}$ is sufficiently large), Equation (A7) will be positive. ${ }^{6}$ Alternatively, a sufficient condition for a positive sign is that both $\mu^{\prime \prime}(I)=0$ and $h^{\prime \prime}(I)=0$.

\section{(6) The auditor's optimal independence choice}

An external auditor considers how much $I$ units of independence she should maintain in her engagement with a client, where $I$ is selected from the real range $\left[I_{\min }, I_{\max }\right]$. The profit function for the external auditor, which is assumed to be twice continuously differentiable, is.

$$
\pi=K g(I)-C[h(I)]^{\lambda}, \lambda>1
$$

Here $K g(I)$ represents the revenue function whereby $g^{\prime}(I)<0$ - so higher independence causes a reduction in revenues - and $K$ is the dollar revenue lost when independence is increased by one unit. Further assume that $g^{\prime \prime}(I)<0$, implying that the loss to revenues is relatively small as $I$ increases in the vicinity of $I_{\min }-$ i.e., when the auditor is highly dependent on the client - and much larger in the vicinity $\mathrm{f} I_{\max }-$ i.e., when the auditor is highly independent. $C$ represents a cost associated with weaker independence, and this cost is increasing faster with $h$, as is reflected in the condition that $\lambda>1 .^{7}$ 
The auditor's objective is to maximize expression (A8) by optimally choosing $I$. Thus, we need to solve the following expression:

$$
\max _{I} \pi=K g(I)-C h(I)^{\lambda}
$$

The first and second order conditions are given by A10 and A11, respectively:

$$
\begin{gathered}
K g^{\prime}(I)-C \lambda h(I)^{\lambda-1} h^{\prime}(I)=0 \\
K g^{\prime \prime}(I)-C \lambda h(I)^{\lambda-2}\left[(\lambda-1) h^{\prime}(I)^{2}+h(I) h^{\prime \prime}(I)\right]<0
\end{gathered}
$$

The sign of (A11) is negative, confirming it is a maximization problem with a unique solution. ${ }^{8}$ Two important observations arise: First, a higher $K$ will lead to lower auditor independence, because the auditor will optimally select a smaller $I$ while earning higher fees. Second, a higher $C$ leads to higher auditor independence. ${ }^{9}$

\section{(7) The effect of SOX on auditor independence and cost of capital}

The objective of $S O X$ was to cause auditors to become more diligent in the monitoring and reporting activities by imposing restrictions on $N A S$ and the creation of the $P C A O B$, among other requirements. These requirements are essentially equivalent to increasing $C$, the cost associated with weaker independence. On the other hand, the rent $K$ charged by auditors for giving up a unit of independence could increase following $S O X$. This is plausible because auditors now face a tougher litigation environment, so they may demand a higher rent following SOX.

To find out the effect of $S O X$ on $I$ and, in turn, on $\beta$, consider a continuous variable $L$ that represent the strictness of the legal environment. To the extent that SOX makes the legal environment stricter, it will work to increase $L$. Let $\partial K / \partial L$ represent the effect of changing the 
legal environment on the auditor's revenues and let $\partial C / \partial L$ denote the effect on cost. Therefore the effect on the equilibrium level of independence is given by

$$
\frac{d I}{d L}=\left[\frac{\partial I}{\partial K} \frac{\partial K}{\partial L}+\frac{\partial I}{\partial C} \frac{\partial C}{\partial L}\right]
$$

Note that the sign of (A12) is ambiguous because $\partial I / \partial K<0$ and $\partial I / \partial C>0$. We believe that the sign of (A12) on empirical grounds is likely positive. This is quite plausible, as the main focus of $S O X$ was to create a framework that penalizes lack of independence. Furthermore, Table 3 indicates that total fees have declined after $S O X$, which in turn suggests auditors may not have been able to charge more for collusion with managers while keeping the same level of independence. Had SOX reduced auditor independence we would expect total fees to increase after its enactment.

Now, the effect of $S O X$ on $\beta$ can be expressed as

$$
\frac{d \beta}{d L}=\frac{\partial \beta}{\partial I} \frac{d I}{d L}
$$

Our main findings are consistent with a positive sign of (A13) as we find stronger negative association between auditor independence and cost of capital in the post-SOX period. 
Table 1

Panel A: Estimating an Expectation Model for RAUD (Quasi-Likelihood Method)*

\begin{tabular}{|c|c|c|c|c|c|c|c|}
\hline & 2000 & 2001 & 2002 & 2003 & 2004 & 2005 & 2006 \\
\hline \multirow[t]{2}{*}{ ROA } & 0.16 & 0.08 & 0.06 & -0.07 & -0.10 & -0.02 & -0.92 \\
\hline & $(0.93)$ & $(0.74)$ & $(0.48)$ & $(-0.37)$ & $(-0.40)$ & $(-0.16)$ & $(-3.59)^{* * *}$ \\
\hline \multirow[t]{2}{*}{ LOSS } & 0.12 & -0.01 & 0.04 & 0.06 & 0.13 & 0.06 & 0.02 \\
\hline & $(1.85)^{*}$ & $(-0.19)$ & $(0.70)$ & $(1.91)^{*}$ & $(2.02)^{* *}$ & $(2.28)^{* *}$ & $(0.26)$ \\
\hline \multirow[t]{2}{*}{ MRET } & -0.00 & 0.01 & 0.05 & 0.04 & -0.06 & 0.05 & -0.01 \\
\hline & $(-0.07)$ & $(0.34)$ & (1.09) & $(1.93)^{*}$ & $(-2.53)^{* *}$ & $(1.94)^{*}$ & $(-0.26)$ \\
\hline \multirow[t]{2}{*}{ CFO } & -0.08 & -0.39 & -0.33 & -0.33 & -0.06 & -0.36 & -0.77 \\
\hline & $(-0.34)$ & $(-2.46)^{* *}$ & $(-1.89)^{*}$ & $(-1.65)^{*}$ & $(-0.26)$ & $(-2.02)^{* *}$ & $(-2.79)^{* * *}$ \\
\hline \multirow[t]{2}{*}{$L E V$} & 0.22 & 0.06 & -0.10 & 0.04 & -0.16 & 0.00 & -0.14 \\
\hline & $(1.79)^{*}$ & $(0.53)$ & $(-0.89)$ & $(0.34)$ & $(-1.36)$ & $(0.03)$ & $(-1.09)$ \\
\hline \multirow[t]{2}{*}{ INVREC } & 0.23 & 0.08 & 0.11 & 0.20 & -0.11 & 0.01 & 0.32 \\
\hline & $(1.70)^{*}$ & $(0.68)$ & $(0.99)$ & $(1.74)^{*}$ & $(-0.83)$ & $(0.11)$ & $(2.15)^{* *}$ \\
\hline \multirow[t]{2}{*}{ SIZE } & -0.27 & -0.24 & -0.13 & -0.10 & -0.05 & -0.06 & -0.04 \\
\hline & $(-20.04)^{* * *}$ & $(-19.10)^{* * *}$ & $(-11.19)^{* * *}$ & $(-9.57)^{* * *}$ & $(-3.54)^{* * *}$ & $(-5.64)^{* * *}$ & $(-2.46)^{* *}$ \\
\hline \multirow[t]{2}{*}{ MB } & -0.00 & -0.00 & -0.01 & -0.01 & -0.01 & -0.00 & -0.01 \\
\hline & $(-0.12)$ & $(-1.77)^{*}$ & $(-1.95)^{*}$ & $(-1.92)^{*}$ & $(-2.61)^{* *}$ & $(-0.29)$ & $(-2.34)^{* *}$ \\
\hline \multirow[t]{2}{*}{ SALEG } & -0.03 & -0.04 & -0.07 & 0.01 & 0.03 & 0.03 & 0.06 \\
\hline & $(-0.51)$ & $(-0.77)$ & $(-2.16)^{* *}$ & $(0.20)$ & $(0.46)$ & $(0.40)$ & $(0.23)$ \\
\hline \multirow[t]{2}{*}{ MA } & -0.15 & -0.15 & -0.07 & -0.12 & -0.06 & -0.13 & -0.27 \\
\hline & $(-0.80)$ & $(-2.05)^{* *}$ & $(-0.83)$ & $(-2.43)^{* *}$ & $(-0.64)$ & $(-1.97)^{* *}$ & $(-3.64)^{* * *}$ \\
\hline \multirow[t]{2}{*}{ SEG } & 0.01 & 0.00 & 0.01 & -0.00 & 0.01 & 0.01 & 0.04 \\
\hline & $(2.77)^{* * *}$ & $(0.45)$ & $(2.20)^{* *}$ & $(-0.15)$ & $(0.82)$ & $(2.07)^{* *}$ & $(2.58)^{* *}$ \\
\hline \multirow[t]{2}{*}{ AUDDUM } & -0.19 & -0.42 & -0.23 & -0.06 & 0.09 & 0.27 & 0.37 \\
\hline & $(-2.12)^{* *}$ & $(-5.49)^{* * *}$ & $(-3.38)^{* * *}$ & $(-0.98)$ & $(2.37)^{* *}$ & $(5.65)^{* * *}$ & $(5.29)^{* * *}$ \\
\hline \multirow[t]{2}{*}{ TENU } & 0.19 & 0.07 & -0.07 & -0.05 & -0.01 & 0.01 & -0.05 \\
\hline & $(3.30)^{* * *}$ & $(1.80)^{*}$ & $(-1.71)^{*}$ & $(-1.83)^{*}$ & $(-0.24)$ & $(0.77)$ & $(-0.67)$ \\
\hline \multirow[t]{2}{*}{ SWITCH } & -0.47 & 0.34 & 0.07 & -0.03 & -0.07 & 0.11 & -0.01 \\
\hline & $(-3.75)^{* * *}$ & $(3.03)^{* * *}$ & $(0.91)$ & $(-0.30)$ & $(-0.70)$ & $(2.22)^{* *}$ & $(-0.09)$ \\
\hline \multirow[t]{2}{*}{$L I T$} & 0.07 & 0.05 & -0.00 & 0.02 & 0.02 & 0.04 & 0.01 \\
\hline & $(3.53)^{* * *}$ & $(2.87)^{* * *}$ & $(-0.10)$ & $(1.82)^{*}$ & $(2.01)^{* *}$ & $(2.98)^{* * *}$ & $(0.62)$ \\
\hline Observations & 1,981 & 2,821 & 3,509 & 3,539 & 3,697 & 3,108 & 3,118 \\
\hline Log Likelihood & $-1,208$ & $-1,658$ & $-1,913$ & $-1,984$ & $-1,751$ & $-1,234$ & $-1,337$ \\
\hline Prob $>$ Chi2 & 0 & 0 & 0 & 0 & 0 & 0 & 0 \\
\hline
\end{tabular}


Table 1 (Continue)

Panel B: Estimating an Expectation Model for LTFEE

\begin{tabular}{|c|c|c|c|c|c|c|c|}
\hline & 2000 & 2001 & 2002 & 2003 & 2004 & 2005 & 2006 \\
\hline \multirow[t]{2}{*}{ ROA } & -0.89 & -0.42 & -0.76 & -0.92 & -0.57 & -0.53 & -0.76 \\
\hline & $(-6.00)^{* * *}$ & $(-4.61)^{* * *}$ & $(-6.92)^{* * *}$ & $(-6.92)^{* * *}$ & $(-4.10)^{* * *}$ & $(-5.65)^{* * *}$ & $(-6.45)^{* * *}$ \\
\hline \multirow[t]{2}{*}{ LOSS } & -0.08 & 0.06 & 0.06 & 0.09 & 0.09 & 0.11 & 0.05 \\
\hline & $(-1.50)$ & (1.59) & (1.47) & $(2.26)^{* *}$ & $(2.06)^{* *}$ & $(3.78)^{* * *}$ & (1.33) \\
\hline \multirow[t]{2}{*}{ MRET } & -0.12 & 0.01 & 0.01 & 0.02 & -0.03 & -0.06 & 0.02 \\
\hline & $(-3.92)^{* * *}$ & $(0.58)$ & $(0.45)$ & $(1.58)$ & $(-3.32)^{* * *}$ & $(-3.22)^{* * *}$ & $(0.57)$ \\
\hline \multirow[t]{2}{*}{ CFO } & 0.23 & -0.16 & 0.36 & 0.41 & -0.01 & -0.11 & 0.31 \\
\hline & $(1.26)$ & $(-1.27)$ & $(2.47)^{* *}$ & $(2.71)^{* * *}$ & $(-0.08)$ & $(-1.09)$ & $(2.29)^{* *}$ \\
\hline \multirow[t]{2}{*}{$L E V$} & -0.24 & -0.10 & 0.08 & 0.02 & 0.24 & 0.04 & -0.00 \\
\hline & $(-2.35)^{* *}$ & $(-1.21)$ & $(0.90)$ & $(0.25)$ & $(2.84)^{* * *}$ & $(0.80)$ & $(-0.01)$ \\
\hline \multirow[t]{2}{*}{ INVREC } & 0.63 & 0.67 & 0.77 & 0.63 & 0.61 & 0.52 & 0.48 \\
\hline & $(5.80)^{* * *}$ & $(7.54)^{* * *}$ & $(8.07)^{* * *}$ & $(7.35)^{* * *}$ & $(7.01)^{* * *}$ & $(9.17)^{* * *}$ & $(5.76)^{* * *}$ \\
\hline \multirow[t]{2}{*}{ SIZE } & 0.68 & 0.65 & 0.61 & 0.60 & 0.58 & 0.57 & 0.58 \\
\hline & $(56.82)^{* * *}$ & $(65.17)^{* * *}$ & $(60.31)^{* * *}$ & $(66.39)^{* * *}$ & $(61.57)^{* * *}$ & $(88.58)^{* * *}$ & $(60.83)^{* * *}$ \\
\hline \multirow[t]{2}{*}{ MB } & 0.02 & 0.01 & 0.01 & 0.02 & 0.01 & 0.01 & 0.01 \\
\hline & $(4.21)^{* * *}$ & $(2.13)^{* *}$ & $(1.93)^{*}$ & $(5.23)^{* * *}$ & $(3.65)^{* * *}$ & $(3.27)^{* * *}$ & $(3.27)^{* * *}$ \\
\hline \multirow[t]{2}{*}{ SALEG } & -0.12 & -0.09 & -0.03 & 0.00 & -0.12 & -0.09 & -0.27 \\
\hline & $(-2.01)^{* *}$ & $(-1.81)^{*}$ & $(-0.51)$ & $(0.04)$ & $(-2.73)^{* * *}$ & $(-2.06)^{* *}$ & $(-0.90)$ \\
\hline \multirow[t]{2}{*}{$M A$} & 0.24 & 0.23 & 0.27 & 0.19 & 0.17 & 0.18 & 0.06 \\
\hline & $(1.45)$ & $(3.50)^{* * *}$ & $(3.47)^{* * *}$ & $(2.42)^{* *}$ & $(2.48)^{* *}$ & $(4.19)^{* * *}$ & $(1.14)$ \\
\hline \multirow[t]{2}{*}{ SEG } & 0.05 & 0.05 & 0.05 & 0.07 & 0.05 & 0.05 & 0.05 \\
\hline & $(4.47)^{* * *}$ & $(6.13)^{* * *}$ & $(5.34)^{* * *}$ & $(8.15)^{* * *}$ & $(6.26)^{* * *}$ & $(8.70)^{* * *}$ & $(5.44)^{* * *}$ \\
\hline \multirow[t]{2}{*}{ AUDDUM } & 0.09 & 0.18 & 0.23 & 0.24 & 0.51 & 0.37 & 0.43 \\
\hline & $(1.36)$ & $(3.52)^{* * *}$ & $(4.63)^{* * *}$ & $(5.53)^{* * *}$ & $(12.03)^{* * *}$ & $(13.76)^{* * *}$ & $=(11.38)^{* * *}$ \\
\hline \multirow[t]{2}{*}{ TENU } & -0.03 & -0.01 & 0.07 & 0.08 & 0.08 & 0.04 & 0.16 \\
\hline & $(-0.75)$ & $(-0.44)$ & $(2.14)^{* *}$ & $(3.63)^{* * *}$ & $(3.12)^{* * *}$ & $(3.43)^{* * *}$ & $(3.74)^{* * *}$ \\
\hline \multirow[t]{2}{*}{ SWITCH } & -0.07 & -0.43 & -0.56 & -0.24 & -0.14 & -0.21 & -0.23 \\
\hline & $(-0.77)$ & $(-6.11)^{* * *}$ & $(-9.08) * * *$ & $(-4.13)^{* * *}$ & $(-2.42)^{* *}$ & $(-6.55)^{* * *}$ & $(-5.33) * * *$ \\
\hline \multirow[t]{2}{*}{$L I T$} & 0.02 & 0.01 & 0.03 & 0.04 & 0.03 & 0.03 & 0.03 \\
\hline & $(1.00)$ & $(0.50)$ & $(2.27)^{* *}$ & $(2.81)^{* * *}$ & $(2.23)^{* *}$ & $(3.76)^{* * *}$ & $(2.19)^{* *}$ \\
\hline Observations & 1,981 & 2,821 & 3,509 & 3,539 & 3,697 & 3,108 & 3,118 \\
\hline $\operatorname{Adj}-R^{2}$ & 0.75 & 0.77 & 0.71 & 0.76 & 0.75 & 0.76 & 0.74 \\
\hline
\end{tabular}

Notes:

1. The Table presents annual results for estimating equations (1) with $R A U D$ as the dependent variable in Panel A (using the Quasi-Likelihood method), and with LTFEE as the dependent variable in Panel B (using OLS). Regressions include industry fixed effects (not tabulated). 
2. Dependent variables are defined as follows: RAUD is measured as audit fees paid by client $\mathrm{i}$ to audit firm $\mathrm{j}$ divided by total fees paid by client $\mathrm{i}$ to audit firm $\mathrm{j}$. UNEXPRAUD denotes unexpected values of $R A U D$ based on regression residuals obtained from annual regression models as described in Panel A. LTFEE is the natural logarithm of total fees (audit and nonaudit) received by the external auditor $\mathrm{j}$ from client i. UNEXPLTFEE denotes unexpected values of [(-1) x LTFEE], based on regression residuals obtained from annual regression models as described in Panel B.

3. Independent variables are defined as follows: $\mathbf{R O A}$ denotes return on assets, measured as net income before extraordinary items (Compustat item \#18) divided by total assets (item \#6). LOSS is an indicator variable that obtains the value of " 1 " if the firm reports negative net income (item \#18), and "0"otherwise. MRET is market-adjusted annual stock return, measured as the difference between raw return for a specific firm minus the return on a value-weighted market portfolio obtained from CRSP. CFO denotes cash flows from operations (item \#308) divided by total assets (item \#6). $\boldsymbol{L} \boldsymbol{E} \boldsymbol{V}$ denotes leverage, measured as the ratio of long term debt (data \#9) over total assets (data \#6). INVREC denotes inventory (item \#3) plus accounts receivable (item \#2) divided by total assets (item \#6). SIZE is measured as $\log (1+$ total assets $)=\log (1+$ Compustat data \#6). MB denotes market-to-book ratio, measured as market value of equity (item \#25 multiplied by item \#199) divided by book value of equity (item \#216). SALEG denotes sales growth, measured as average percentage change in sales over the last three years. $\boldsymbol{M A}$ is an indicator variable, taking the value of " 1 " if there is merger and acquisition activity in the current year, and " 0 " otherwise. SEG is the number of business segments. AUDDUM is an indicator variable, equal to "1" if the auditor belongs to Big-4, and " 0 " otherwise. TENU is the natural logarithm of (1+TENURE), where TENURE is the length of the auditor-client relationship, measured as the number of years the firm has been consistently audited by the current auditor, as of the bond filing date and based on Compustat. SWITCH is an indicator variable, equal to " 1 " if a bond-issuing firm switches to a different audit firm in the fiscal year prior to the bond issuance, and "0" otherwise. LIT is litigation risk, measured as the standard deviation of monthly return for the past 36 months.

4 . *,**,*** Indicate significance at the $0.10,0.05$, and 0.01 levels, respectively. We report the coefficient estimate and two-tailed $t$-stats (below each coefficient). 
Table 2

Sample Selection - Bond Issuances*

\begin{tabular}{lc}
\hline Panel A: Sampling Criterion & Observations \\
\hline $\begin{array}{l}\text { Bonds that are rated by either Moody's or S\&P's, excluding utilities } \\
\text { and financial institutions and bonds with maturities of less than one }\end{array}$ & 3,214 \\
year & \\
Missing bond yield premium & $\underline{(870)}$ \\
& 2,344 \\
Loss of observations on merging SDC bond data with Compustat and & $\underline{(374)}$ \\
Audit Analytics data & 1,970 \\
Missing financial data & $\underline{(168)}$ \\
Final sample & 1,802 \\
\hline
\end{tabular}

\section{Panel B: Sample Selection by Industry}

\begin{tabular}{llcc}
\hline & & Observations & Firms \\
\hline FF1 & Consumer Non Durables & 145 & 39 \\
FF2 & Consumer Durables & 291 & 19 \\
FF3 & Manufacturing & 430 & 58 \\
FF4 & Oil, Gas and Coal Extraction and Products & 69 & 34 \\
FF5 & Chemicals and Allied Products & 147 & 30 \\
FF6 & Business Equipment & 88 & 29 \\
FF7 & Telephone and Television Transmission & 90 & 26 \\
FF8 & Utilities & - & - \\
FF9 & Wholesale, Retail and Some Services & 132 & 38 \\
FF10 & Healthcare, Medical Equipment, and Drugs & 63 & 28 \\
FF11 & Finance & - & - \\
FF12 & Other & 347 & 61 \\
Total & & $\mathbf{1 , 8 0 2}$ & $\mathbf{3 6 2}$ \\
\hline
\end{tabular}

*Note: Panel A presents details of the total sample selection. Panel B presents the number of observations and firms by industry according to Fama \& French's 12-industry classification (http://mba.tuck.dartmouth.edu/pages/faculty/ken.french). Utilities and Financial Institutions are excluded from the sample. 
Table 3

Descriptive Statistics - Bond Issuances Sample*

Panel A: Descriptive Statistics

\begin{tabular}{|c|c|c|c|c|c|c|c|c|}
\hline & \multicolumn{3}{|c|}{ Pre-Sox } & \multicolumn{3}{|c|}{ Post-SOX } & \multirow{2}{*}{$\frac{t \text {-test }}{\text { (p-value) }}$} & \multirow{2}{*}{$\begin{array}{r}\text { Wilcoxon } \\
\text { (p-value) }\end{array}$} \\
\hline & Mean & Median & STD & Mean & Median & STD & & \\
\hline SPREAD & 1.55 & 1.20 & 1.11 & 1.80 & 1.60 & 1.13 & $-4.6(0.00)$ & $-6.4(0.00)$ \\
\hline RATING & 6.86 & 7.00 & 3.29 & 8.03 & 8.00 & 3.04 & $-7.4(0.00)$ & $-6.6(0.00)$ \\
\hline ISIZE & 0.07 & 0.05 & 0.09 & 0.04 & 0.03 & 0.08 & $6.9(0.00)$ & $3.6(0.00)$ \\
\hline OSCORE & -1.50 & -1.43 & 2.91 & -1.33 & -1.38 & 2.39 & $-1.3(0.21)$ & $-1.3(0.18)$ \\
\hline COVR & 6.72 & 4.58 & 10.01 & 6.95 & 4.03 & 9.28 & $-0.5(0.63)$ & $1.0(0.36)$ \\
\hline RAUD & 0.39 & 0.45 & 0.33 & 0.68 & 0.73 & 0.26 & $-19.3(0.00)$ & $-11.9(0.00)$ \\
\hline UNEXPRAUD & 0.18 & 0.17 & 0.25 & 0.10 & 0.07 & 0.21 & $7.3(0.00)$ & $6.1(0.00)$ \\
\hline LTFEE & 16.48 & 16.49 & 1.63 & 16.10 & 15.90 & 1.35 & $5.0(0.00)$ & $6.5(0.00)$ \\
\hline UNEXPLTFEE & -0.04 & -0.09 & 1.16 & -0.19 & -0.17 & 0.86 & $2.9(0.00)$ & $3.6(0.00)$ \\
\hline SIZE & 10.12 & 10.18 & 1.19 & 9.81 & 9.97 & 1.26 & $5.0(0.00)$ & $5.0(0.00)$ \\
\hline$L E V$ & 0.39 & 0.38 & 0.17 & 0.32 & 0.28 & 0.16 & $7.8(0.00)$ & $7.2(0.00)$ \\
\hline SALEG & 0.13 & 0.09 & 0.28 & 0.12 & 0.10 & 0.16 & $1.2(0.23)$ & $-1.4(0.17)$ \\
\hline ROA & 0.10 & 0.10 & 0.07 & 0.08 & 0.07 & 0.07 & $7.0(0.00)$ & $6.7(0.00)$ \\
\hline LOSS & 0.12 & 0.00 & 0.33 & 0.11 & 0.00 & 0.31 & $0.9(0.36)$ & $0.9(0.36)$ \\
\hline MRET & 0.14 & 0.11 & 0.34 & 0.05 & 0.01 & 0.27 & $5.2(0.00)$ & $6.0(0.00)$ \\
\hline CFO & 0.11 & 0.12 & 0.06 & 0.11 & 0.10 & 0.06 & $0.6(0.54)$ & $1.1(0.28)$ \\
\hline INVREC & 0.21 & 0.19 & 0.14 & 0.23 & 0.22 & 0.18 & $-1.3(0.21)$ & $-1.1(0.29)$ \\
\hline MB & 5.15 & 3.52 & 5.77 & 3.56 & 2.69 & 3.55 & $5.9(0.00)$ & $3.9(0.00)$ \\
\hline AUDDUM & 1.00 & 1.00 & 0.05 & 0.99 & 1.00 & 0.10 & $1.1(0.29)$ & $1.1(0.29)$ \\
\hline SWITCH & 0.09 & 0.00 & 0.29 & 0.03 & 0.00 & 0.18 & $4.4(0.00)$ & $4.4(0.00)$ \\
\hline TENU & 2.42 & 2.64 & 0.62 & 1.96 & 2.30 & 0.88 & $9.8(0.00)$ & $1.3(0.21)$ \\
\hline MA & 0.11 & 0.00 & 0.32 & 0.15 & 0.00 & 0.36 & $-1.8(0.07)$ & $-1.8(0.07)$ \\
\hline$S E G$ & 3.07 & 1.00 & 2.48 & 3.37 & 3.00 & 2.29 & $-2.2(0.03)$ & $-3.0(0.00)$ \\
\hline LIT & 0.82 & 0.80 & 1.72 & 0.68 & 0.65 & 1.40 & $1.8(0.08)$ & $3.1(0.00)$ \\
\hline
\end{tabular}

Panel B: Means and medians of RAUD and LTFEE by year

\begin{tabular}{lccccccccc}
\hline RAUD & 2000 & 2001 & $\begin{array}{c}2002 \\
\text { Pre }\end{array}$ & $\begin{array}{c}2002 \\
\text { Post }\end{array}$ & 2003 & 2004 & 2005 & 2006 & Total \\
\hline Mean & 0.33 & 0.33 & 0.51 & 0.57 & 0.60 & 0.73 & 0.78 & 0.79 & 0.55 \\
Median & 0.29 & 0.25 & 0.57 & 0.64 & 0.61 & 0.74 & 0.77 & 0.78 & 0.64 \\
\hline LTFEE & & & & & & & & & \\
Mean & 16.51 & 16.29 & 16.74 & 16.59 & 15.98 & 16.15 & 15.91 & 15.69 & 16.26 \\
Median & 16.94 & 15.92 & 16.88 & 16.84 & 15.79 & 15.99 & 15.97 & 15.71 & 16.05 \\
\hline Observations & 167 & 362 & 248 & 221 & 251 & 234 & 130 & 189 & 1,802 \\
\hline
\end{tabular}

Note: The Table presents descriptive statistics for the variables used in this study. RATING denotes Moody's bond rating on a cardinal scale from 1 for Aaa to 22 for D; SPREAD is the 
difference in percentage points between the yield-to-maturity for the corporate bond and that of a U.S. treasury bond with comparable maturity; ISIZE is the size of the debt issue, measured as the ratio of total principal amount of the bond over firm's total assets; OSCORE is a measure of default risk based on the coefficients obtained by Ohlson (1980); COVR is the interest coverage ratio, measured as operating income after depreciation (Compustat data \#178) divided by interest expenses (data \#15). All other variables are as defined in Table 1. 
Table 4

Selected Correlations*

\begin{tabular}{|c|c|c|c|c|c|c|c|c|c|c|c|c|c|c|}
\hline & & 1 & 2 & 3 & 4 & 5 & 6 & 7 & 8 & 9 & 10 & 11 & 12 & 13 \\
\hline 1 & SPREAD & & 0.70 & 0.35 & 0.32 & -0.17 & 0.14 & -0.11 & 0.37 & -0.02 & 0.33 & -0.29 & -0.25 & 0.22 \\
\hline 2 & RATING & 0.71 & & 0.33 & 0.28 & -0.11 & 0.12 & -0.19 & 0.36 & -0.11 & 0.18 & -0.42 & -0.36 & 0.09 \\
\hline 3 & ISIZE & 0.44 & 0.43 & & 0.85 & 0.72 & 0.62 & 0.38 & 0.81 & 0.68 & 0.16 & -0.05 & -0.15 & 0.79 \\
\hline 4 & OSCORE & 0.46 & 0.39 & 0.67 & & 0.74 & 0.55 & 0.50 & 0.81 & 0.66 & 0.17 & -0.38 & -0.07 & 0.77 \\
\hline 5 & UNEXPRAUD & -0.20 & -0.12 & 0.53 & 0.59 & & -0.32 & 0.49 & 0.69 & 0.66 & 0.02 & 0.06 & 0.24 & 0.67 \\
\hline 6 & UNEXPLTFEE & 0.17 & 0.09 & 0.59 & 0.51 & -0.39 & & 0.50 & 0.47 & 0.44 & -0.12 & -0.03 & -0.25 & 0.57 \\
\hline 7 & SIZE & -0.08 & -0.12 & 0.26 & 0.33 & 0.51 & 0.58 & & 0.37 & 0.44 & -0.19 & -0.04 & -0.02 & 0.54 \\
\hline 8 & $\boldsymbol{L E V}$ & 0.41 & 0.37 & 0.68 & 0.83 & 0.61 & 0.52 & 0.39 & & 0.58 & 0.15 & -0.13 & 0.12 & 0.68 \\
\hline 9 & ROA & -0.05 & -0.14 & 0.51 & 0.41 & 0.60 & 0.56 & 0.48 & 0.48 & & 0.10 & 0.65 & 0.58 & 0.71 \\
\hline 10 & MRET & 0.21 & 0.13 & -0.02 & 0.11 & 0.12 & -0.16 & -0.14 & 0.13 & 0.09 & & 0.07 & 0.03 & 0.12 \\
\hline 11 & CFO & -0.41 & -0.47 & -0.14 & -0.37 & 0.00 & 0.07 & -0.05 & -0.19 & 0.72 & 0.08 & & 0.48 & 0.10 \\
\hline 12 & $M B$ & -0.47 & -0.57 & -0.28 & -0.14 & 0.06 & 0.01 & 0.11 & -0.12 & 0.63 & 0.08 & 0.56 & & 0.02 \\
\hline 13 & $L I T$ & 0.28 & 0.23 & 0.59 & 0.54 & 0.49 & 0.51 & 0.41 & 0.55 & 0.59 & 0.18 & 0.04 & -0.04 & \\
\hline
\end{tabular}

Note: The Table presents pair-wise correlations for selected variables. Pearson (Spearman) correlations are presented above (below) the diagonal. Correlations above 0.06 and below -0.06 are significant at the 0.05 level. The variables are: $\boldsymbol{S P R E A D}$ is the difference in percentage points between the yield-to-maturity for the corporate bond and that of a U.S. treasury bond with comparable maturity; RATING is Moody's bond rating on a cardinal scale from 1 for Aaa to 22 for D; ISIZE is the size of the debt issue, measured as the ratio of total principal amount of the bond over firm's total assets; OSCORE is a measure of default risk based on the coefficients obtained by Ohlson (1980); UNEXPRAUD is unexpected values of the ratio of audit fees to total fees; UNEXPLTFEE denotes unexpected values of $\log$ of total fees; SIZE is measured as $\log (1+$ Compustat data \#6). LEV denotes leverage, measured as the ratio of long term debt (data \#9) over total assets (data \#6). ROA denotes return on assets, measured as net income before extraordinary items (Compustat item \#18) divided by total assets (item \#6). MRET is market-adjusted annual stock return, measured as the difference between raw return for a specific firm minus the return on a value-weighted market portfolio obtained from CRSP. CFO denotes cash flows from operations (item \#308) divided by total assets (item \#6). MB denotes market-to-book ratio, measured as market value of equity (item \#25 multiplied by item \#199) divided by book value of equity (item \#216). LIT is litigation risk, measured as the standard deviation of monthly return for the past 36 months. 


\section{Table 5}

The Association between Auditor Independence (UNEXPRAUD) and Bond Rating (RATING) and Yield Spread (SPREAD)*

\begin{tabular}{lcccccc} 
& \multicolumn{2}{c}{ Bond Rating (RATING) } & \multicolumn{3}{c}{ Yield Spread (SPREAD) } \\
& Pre-SOX & Post-SOX & Difference & Pre-SOX & Post-SOX & Difference \\
\hline UNEXPRAUD & -1.25 & -1.64 & -0.39 & 0.04 & -0.26 & -0.30 \\
& $(-3.03)^{* * *}$ & $(-3.18)^{* * *}$ & $(-2.16)^{* *}$ & $(1.32)$ & $(-2.23)^{* *}$ & $(-2.01)^{* *}$ \\
RATING & & & & 0.19 & 0.21 & 0.02 \\
& & & & $(12.60)^{* * *}$ & $(14.35)^{* * *}$ & $(0.23)$ \\
ISIZE & 15.54 & 13.50 & -2.04 & 3.25 & 1.20 & -2.05 \\
& $(4.89)^{* * *}$ & $(4.75)^{* * *}$ & $(-0.68)$ & $(3.13)^{* * *}$ & $(1.10)$ & $(-2.31)^{* *}$ \\
SIZE & -0.75 & -0.73 & 0.02 & -0.21 & -0.09 & 0.12 \\
& $(-6.01)^{* * *}$ & $(-8.11)^{* * *}$ & $(0.13)$ & $(-5.13)^{* * *}$ & $(-2.39)^{* *}$ & $(2.16)^{* *}$ \\
LEV & 3.42 & 3.33 & -0.09 & 0.54 & 1.07 & 0.53 \\
& $(3.31)^{* * *}$ & $(4.00)^{* * *}$ & $(-0.51)$ & $(1.61)$ & $(3.33)^{* * *}$ & $(1.47)$ \\
OSCORE & 0.08 & 0.12 & 0.04 & 0.04 & 0.02 & -0.02 \\
& $(2.53)^{* *}$ & $(5.15)^{* * *}$ & $(1.05)$ & $(3.29)^{* * *}$ & $(2.68)^{* * *}$ & $(-1.52)$ \\
COVR & -0.19 & -0.11 & 0.08 & -0.02 & -0.02 & -0.00 \\
& $(-7.89)^{* * *}$ & $(-5.54)^{* * *}$ & $(2.39)^{* *}$ & $(-2.17)^{* *}$ & $(-2.89)^{* * *}$ & $(-0.39)$ \\
ROA & -5.74 & -8.64 & -2.90 & -2.94 & -3.19 & -0.25 \\
& $(-2.18)^{* *}$ & $(-5.85)^{* * *}$ & $(-2.48)^{* *}$ & $(-3.49)^{* * *}$ & $(-4.62)^{* * * *}$ & $(-1.03)$ \\
LIT & 0.60 & 0.80 & 0.20 & 0.11 & 0.12 & 0.01 \\
& $(6.57)^{* * *}$ & $(6.82)^{* * *}$ & $(1.99)^{*}$ & $(3.74)^{* * *}$ & $(2.51)^{* *}$ & $(0.83)$ \\
SOX & & & 0.86 & & & -0.32 \\
& & & $(0.53)$ & & & $(-2.40)^{* *}$ \\
No. of Obs. & 518 & 1,284 & 1,802 & 518 & 1,284 & 1,802 \\
Adj-R & 0.74 & 0.62 & 0.69 & 0.72 & 0.65 & 0.67 \\
\hline
\end{tabular}

*Notes:

1. The Table presents results for estimating equations (2a) and (2b) using $O L S$ with industry fixed effects (not tabulated). See Tables 1 and 3 for variable definitions.

2. The regression models are:

$$
\begin{aligned}
& \text { RATING }_{i}=\alpha+\beta_{1} \text { UNEXPRAUD }_{i}+\beta_{2} \text { ISIZE }_{i}+\beta_{3} \text { SIZE }_{i}+\beta_{4} \text { LEV }_{i}+\beta_{5} \text { OSCORE }_{i}+ \\
& \beta_{6} \text { COVR }_{i}+\beta_{7} \text { ROA }_{i}+\beta_{8} \text { LIT }_{i}+v_{i} \\
& \text { SPREAD }_{i}=\alpha+\beta_{1} \text { UNEXPRAUD }_{i}+\beta_{2} \text { RATING }_{i}+\beta_{3} \text { ISIZE }_{i}+\beta_{4} \text { SIZE }_{i}+ \\
& \beta_{5} \text { LEV }_{i}+\beta_{6} \text { OSCORE }_{i}+\beta_{7} \text { COVR }_{i}+\beta_{8} \text { ROA }_{i}+\beta_{9} \text { LIT }_{i}+v_{i}
\end{aligned}
$$

3. *,**,*** Indicate significance at the $0.10,0.05$, and 0.01 levels, respectively. We report coefficient estimates and $t$-statistics (below each coefficient). 
Table 6

The Association between Auditor Independence (UNEXPLTFEE) and Bond Rating (RATING) and Yield Spread (SPREAD)*

\begin{tabular}{|c|c|c|c|c|c|c|}
\hline & \multicolumn{3}{|c|}{ Bond Rating (RATING) } & \multicolumn{3}{|c|}{ Yield Spread (SPREAD) } \\
\hline & Pre-SOX & Post-SOX & Difference & Pre-SOX & Post-SOX & Difference \\
\hline \multirow[t]{2}{*}{ UNEXPLTFEE } & -0.15 & -0.32 & -0.17 & -0.04 & -0.19 & -0.15 \\
\hline & $(-1.95)^{*}$ & $(-3.09)^{* * *}$ & $(-2.42)^{* *}$ & $(-1.49)$ & $(-2.48)^{* *}$ & $(-2.20)^{* *}$ \\
\hline \multirow{2}{*}{ RATING } & & & & 0.19 & 0.20 & 0.01 \\
\hline & & & & $(12.51)^{* * *}$ & $(14.26)^{* * *}$ & $(0.32)$ \\
\hline \multirow[t]{2}{*}{ ISIZE } & 15.90 & 13.31 & -2.59 & 2.92 & 1.14 & -1.78 \\
\hline & $(5.05)^{* * *}$ & $(4.68) * * *$ & $(-0.87)$ & $(2.83)^{* * *}$ & $(1.04)$ & $(-2.34)^{* *}$ \\
\hline \multirow[t]{2}{*}{ SIZE } & -0.76 & -0.74 & 0.02 & -0.23 & -0.09 & 0.14 \\
\hline & $(-5.98)^{* * *}$ & $(-8.18)^{* * *}$ & $(0.11)$ & $(-5.40)^{* * *}$ & $(-2.40)^{* *}$ & $(2.38)^{* *}$ \\
\hline \multirow[t]{2}{*}{$L E V$} & 3.42 & 3.41 & -0.01 & 0.67 & 1.05 & 0.38 \\
\hline & $(3.27) * * *$ & $(4.09) * * *$ & $(-0.44)$ & $(1.99)^{* *}$ & $(3.28)^{* * *}$ & (1.19) \\
\hline \multirow[t]{2}{*}{ OSCORE } & 0.08 & 0.12 & 0.04 & 0.04 & 0.02 & -0.02 \\
\hline & $(2.52)^{* *}$ & $(5.18)^{* * *}$ & (1.10) & $(3.52) * * *$ & $(2.76)^{* * *}$ & $(-1.56)$ \\
\hline \multirow[t]{2}{*}{ COVR } & -0.18 & -0.10 & 0.08 & -0.02 & -0.02 & -0.00 \\
\hline & $(-7.82)^{* * *}$ & $(-5.40)^{* * *}$ & $(2.68)^{* * *}$ & $(-2.28)^{* *}$ & $(-2.87)^{* * *}$ & $(-0.44)$ \\
\hline \multirow[t]{2}{*}{ ROA } & -5.80 & -8.73 & -2.93 & -2.77 & -3.28 & -0.51 \\
\hline & $(-2.20) * *$ & $(-5.88) * * *$ & $(-2.51)^{* *}$ & $(-3.28) * * *$ & $(-4.70)^{* * *}$ & $(-1.15)$ \\
\hline \multirow[t]{2}{*}{$L I T$} & 0.58 & 0.83 & 0.25 & 0.10 & 0.11 & 0.01 \\
\hline & $(6.51)^{* * *}$ & $(7.04)^{* * *}$ & $(2.10)^{* *}$ & $(3.48)^{* * *}$ & $(2.45)^{* *}$ & $(0.64)$ \\
\hline \multirow[t]{2}{*}{ SOX } & & & 0.85 & & & -0.36 \\
\hline & & & $(0.52)$ & & & $(-2.57)^{* *}$ \\
\hline No. of Obs. & 518 & 1,284 & 1,802 & 518 & 1,284 & 1,802 \\
\hline $\operatorname{Adj}-R^{2}$ & 0.74 & 0.62 & 0.69 & 0.72 & 0.65 & 0.68 \\
\hline
\end{tabular}

*Notes:

1. The Table presents results for estimating equations (2a) and (2b) using OLS with industry fixed effects (not tabulated). See Tables 1 and 3 for variable definitions.

2. The regression models are:

$$
\begin{aligned}
& \text { RATING }_{i}=\alpha+\beta_{1} \text { UNEXPLTFEE }_{i}+\beta_{2} \text { ISIZE }_{i}+\beta_{3} \text { SIZE }_{i}+\beta_{4} L_{E V}+ \\
& \beta_{5} \text { OSCORE }_{i}+\beta_{6} \text { COVR }_{i}+\beta_{7} \text { ROA }_{i}+\beta_{8} \text { LIT }_{i}+v_{i} \\
& \text { SPREAD }_{i}=\alpha+\beta_{1} \text { UNEXPLTFEE }_{i}+\beta_{2} \text { RATING }_{i}+\beta_{3} \text { ISIZE }_{i}+\beta_{4} \text { SIZE }_{i}+ \\
& \beta_{5} \text { LEV }_{i}+\beta_{6} \text { OSCORE }_{i}+\beta_{7} \text { COVR }_{i}+\beta_{8} \text { ROA }_{i}+\beta_{9} \text { LIT }_{i}+v_{i}
\end{aligned}
$$

$3 . *, * *, * * *$ Indicate significance at the $0.10,0.05$, and 0.01 levels, respectively. We report coefficient estimates and $t$-statistics (below each coefficient). 


\section{Table 7}

The Association between Auditor Independence (RAUD) and Bond Rating (RATING) and Yield Spread (SPREAD)*

\begin{tabular}{lcccccc} 
& \multicolumn{2}{c}{ Bond Rating (RATING) } & \multicolumn{3}{c}{ Yield Spread (SPREAD) } \\
& Pre-SOX & Post-SOX & Difference & Pre-SOX & Post-SOX & Difference \\
\hline RAUD & -1.20 & -1.48 & -0.28 & -0.07 & -0.51 & -0.44 \\
& $(-2.43)^{* *}$ & $(-3.59)^{* * *}$ & $(-0.84)$ & $(-2.47)^{* *}$ & $(-3.21)^{* * *}$ & $(-2.83)^{* * *}$ \\
RATING & & & & 0.19 & 0.21 & 0.02 \\
& & & & $(12.52)^{* * *}$ & $(14.70)^{* * *}$ & $(0.70)$ \\
ISIZE & 15.89 & 10.99 & -4.90 & 2.98 & 1.41 & -1.57 \\
& $(5.01)^{* * *}$ & $(3.80)^{* * *}$ & $(-1.34)$ & $(2.87)^{* * *}$ & $(0.36)$ & $(-1.84)^{*}$ \\
SIZE & -0.76 & -0.75 & 0.01 & -0.22 & -0.08 & 0.14 \\
& $(-5.90)^{* * *}$ & $(-8.35)^{* * *}$ & $(0.17)$ & $(-5.18)^{* * *}$ & $(-2.12)^{* *}$ & $(2.57)^{* *}$ \\
LEV & 3.37 & 3.63 & 0.26 & 0.60 & 0.81 & 0.21 \\
& $(3.24)^{* * *}$ & $(4.77)^{* * *}$ & $(0.12)$ & $(1.80)^{*}$ & $(2.47)^{* *}$ & $(0.82)$ \\
OSCORE & 0.08 & 0.11 & 0.03 & 0.04 & 0.02 & -0.02 \\
& $(2.50)^{* *}$ & $(4.92)^{* * *}$ & $(0.91)$ & $(3.42)^{* * *}$ & $(2.83)^{* * *}$ & $(-1.53)$ \\
COVR & -0.18 & -0.10 & 0.08 & -0.02 & -0.02 & -0.00 \\
& $(-7.74)^{* * *}$ & $(-5.01)^{* * *}$ & $(2.82)^{* * *}$ & $(-2.22)^{* *}$ & $(-2.50)^{* *}$ & $(-0.63)$ \\
ROA & -5.97 & -8.34 & -2.37 & -2.88 & -3.08 & -0.20 \\
& $(-2.27)^{* *}$ & $(-6.18)^{* * *}$ & $(-2.73)^{* * *}$ & $(-3.42)^{* * *}$ & $(-4.28)^{* * *}$ & $(-0.97)$ \\
LIT & 0.59 & 0.84 & 0.25 & 0.10 & 0.10 & 0.00 \\
& $(6.32)^{* * *}$ & $(7.22)^{* * *}$ & $(2.02)^{* *}$ & $(3.25)^{* * *}$ & $(2.13)^{* *}$ & $(0.75)$ \\
SOX & & & -0.26 & & & -0.28 \\
& & & $(-0.16)$ & & & $(-2.26)^{* *}$ \\
No. of Obs. & 518 & 1,284 & 1,802 & 518 & 1,284 & 1,802 \\
Adj- $\boldsymbol{R}^{2}$ & 0.74 & 0.63 & 0.70 & 0.72 & 0.64 & 0.66 \\
\hline
\end{tabular}

*Notes:

1. The Table presents results for estimating equations (2a) and (2b) using $O L S$ with industry fixed effects (not tabulated). See Tables 1 and 3 for variable definitions.

2. The regression models are:

$$
\begin{aligned}
& \text { RATING }_{i}=\alpha+\beta_{1} \text { RAUD }_{i}+\beta_{2} \text { ISIZE }_{i}+\beta_{3} \text { SIZE }_{i}+\beta_{4} \text { LEV }_{i}+\beta_{5} \text { OSCORE }_{i}+ \\
& \beta_{6} \text { COVR }_{i}+\beta_{7} \text { ROA }_{i}+\beta_{8} \text { LIT }_{i}+v_{i} \\
& \text { SPREAD }_{i}=\alpha+\beta_{1} \text { RAUD }_{i}+\beta_{2} \text { RATING }_{i}+\beta_{3} \text { ISIZE }_{i}+\beta_{4} \text { SIZE }_{i}+\beta_{5} \text { LEV }_{i}+ \\
& \beta_{6} \text { OSCORE }_{i}+\beta_{7} \text { COVR }_{i}+\beta_{8} \text { ROA }_{i}+\beta_{9} \text { LIT }_{i}+v_{i}
\end{aligned}
$$

3. *,**, *** Indicate significance at the $0.10,0.05$, and 0.01 levels, respectively. We report coefficient estimates and $t$-statistics (below each coefficient). 
Table 8

Sensitivity Analysis using a Reduced Sample of Companies that Issued Debt Before and After SOX*

\begin{tabular}{|c|c|c|c|c|c|c|}
\hline & \multicolumn{3}{|c|}{ Bond Rating (RATING) } & \multicolumn{3}{|c|}{ Yield Spread (SPREAD) } \\
\hline & Pre-SOX & Post-SOX & Diff. & Pre-SOX & Post-SOX & Diff. \\
\hline \multicolumn{7}{|c|}{ Indep. $=$ UNEXPRAUD } \\
\hline UNEXPRAUD & $\begin{array}{c}-1.34 \\
(-3.14)^{* * *}\end{array}$ & $\begin{array}{c}-1.80 \\
(-3.04)^{* * *}\end{array}$ & $\begin{array}{c}-0.46 \\
(-2.68)^{* * *}\end{array}$ & $\begin{array}{c}0.10 \\
(1.08)\end{array}$ & $\begin{array}{c}-0.16 \\
(-2.52)^{* *}\end{array}$ & $\begin{array}{c}-0.26 \\
(-3.15)^{* * *}\end{array}$ \\
\hline$S O X$ & & & $\begin{array}{c}0.43 \\
(0.18)\end{array}$ & & & $\begin{array}{c}-0.27 \\
(-2.01)^{* *}\end{array}$ \\
\hline Observations & 442 & 748 & 1,190 & 442 & 748 & 1,190 \\
\hline $\operatorname{Adj}-R^{2}$ & 0.68 & 0.60 & 0.64 & 0.65 & 0.55 & 0.57 \\
\hline \multicolumn{7}{|c|}{ Indep. $=$ UNEXPLTFEE } \\
\hline UNEXPLTFEE & $\begin{array}{c}-0.20 \\
(-2.35)^{* *}\end{array}$ & $\begin{array}{c}-0.28 \\
(-2.89)^{* * *}\end{array}$ & $\begin{array}{l}-0.08 \\
(-1.42)\end{array}$ & $\begin{array}{c}-0.07 \\
(-1.09)\end{array}$ & $\begin{array}{c}-0.23 \\
(-2.53)^{* *}\end{array}$ & $\begin{array}{c}-0.16 \\
(-2.08)^{* *}\end{array}$ \\
\hline$S O X$ & & & $\begin{array}{c}0.40 \\
(0.21)\end{array}$ & & & $\begin{array}{c}-0.25 \\
(-2.07)^{* *}\end{array}$ \\
\hline Observations & 442 & 748 & 1,190 & 442 & 748 & 1,190 \\
\hline $\operatorname{Adj}-R^{2}$ & 0.68 & 0.61 & 0.63 & 0.65 & 0.55 & 0.56 \\
\hline \multicolumn{7}{|l|}{ Indep. $=$ RAUD } \\
\hline$R A U D$ & $\begin{array}{c}-1.30 \\
(-2.83)^{* * *}\end{array}$ & $\begin{array}{c}-1.37 \\
(-3.59)^{* * *}\end{array}$ & $\begin{array}{c}-0.07 \\
(-0.75)\end{array}$ & $\begin{array}{c}-0.05 \\
(-1.87)^{*}\end{array}$ & $\begin{array}{c}-0.61 \\
(-3.39)^{* * *}\end{array}$ & $\begin{array}{c}-0.56 \\
(-2.94)^{* * *}\end{array}$ \\
\hline$S O X$ & & & $\begin{array}{c}-0.18 \\
(-0.68)\end{array}$ & & & $\begin{array}{c}-0.23 \\
(-2.02)^{* *}\end{array}$ \\
\hline Observations & 442 & 748 & 1,190 & 442 & 748 & 1,190 \\
\hline $\operatorname{Adj}-R^{2}$ & 0.68 & 0.60 & 0.64 & 0.65 & 0.56 & 0.57 \\
\hline
\end{tabular}

*Notes:

1. The Table presents results for estimating equations (2a) and (2b) using OLS with industry fixed effects. We report only the coefficients on the independence measures (UNEXPRAUD, UNEXPLTFEE, and RAUD).

2. See Table 6 for a description of the estimated models and Tables 1 and 3 for variable definitions.

3. *,**,*** Indicate significance at the $0.10,0.05$, and 0.01 levels, respectively. We report a one-tailed $\mathrm{p}$-value for the auditor independence variables (UNEXPRAUD, UNEXPLTFEE, and $R A U D$ ). 


\section{Endnotes}

${ }^{1}$ See SEC Final Rule Release No. 33-8183 (http://www.sec.gov/rules/final/33-8183.htm).

${ }^{2}$ See http://www.pcaobus.org/About the_PCAOB/index.aspx.

${ }^{3}$ SEC argues that these "rules advance our important policy goal of protecting the millions of people who invest in our securities markets in reliance on financial statements that are prepared by public companies and other issuers and that, as required by Congress, are audited by independent auditors ("Strengthening the Commission's Requirements Regarding Auditor Independence” Final Release No. 33-8183, 2003).

${ }^{4}$ All continuous explanatory variables, except the auditor independence variables, are winsorized at $1 \%$ and $99 \%$ to mitigate the effect of extreme observations.

${ }^{5}$ We check whether the results are influenced by heteroscedasticity using the White (1980) approach. The results are very similar to those reported in Tables 5-7.

${ }^{6}$ The specific condition is $h^{\prime}(I)^{2}>\left[\frac{1}{2} h^{\prime \prime}(I)-\frac{u^{\prime \prime}(I)}{\rho \sigma^{4}}\left[\sigma^{2}+h(I)\right]^{2}\right]\left[\sigma^{2}+h(I)\right]$

${ }^{7}$ The assumption behind this condition is that the chance of legal action or loss of reputation is increasing faster the higher the inaccuracy of the financial report $S$. In the extreme case where the auditor allows the report to be meaningless, the penalty is infinitely high (as in the case of Arthur Andersen). This assumption can be relaxed to allow the cost function to be concave (i.e., $0<\lambda<1)$. In addition, $h^{\prime \prime}(I)$ can be assumed to be negative and $g^{\prime \prime}(I)$ to be positive. However, with these alternative assumptions, to ensure an interior solution the sign of the second order condition (A8) should be assumed negative. 
${ }^{8}$ In a more general setting $h^{\prime \prime}(I)$ can be assumed to be negative and $g^{\prime \prime}(I)$ to be positive. However, with these alternative assumptions, to ensure an interior solution the sign of the second order condition (A11) should be assumed negative.

${ }^{9}$ These observations follow from the application of the Implicit Function Theorem to Equation (A10) noting that the sign of Equation (A11) is negative. 